IMFSTAFFDISCUSSIONNOTE

\title{
Causes and Consequences of Income Inequality: A Global Perspective
}

Era Dabla-Norris, Kalpana Kochhar, Nujin Suphaphiphat, Frantisek Ricka, Evridiki Tsounta 
IMFSTAFFDISCUSSIONNOTE

\section{Causes and Consequences of Income Inequality: A Global Perspective}

Era Dabla-Norris, Kalpana Kochhar, Nujin Suphaphiphat, Frantisek Ricka, Evridiki Tsounta 
INTERNATIONAL MONETARY FUND

Strategy, Policy, and Review Department

\section{Causes and Consequences of Income Inequality: A Global Perspective}

Prepared by Era Dabla-Norris, Kalpana Kochhar, Frantisek Ricka, Nujin Suphaphiphat, and Evridiki Tsounta (with contributions from Preya Sharma and Veronique Salins) ${ }^{1}$

Authorized for distribution by Siddharh Tiwari

June 2015

DISCLAIMER: This Staff Discussion Note represents the views of the authors and does not necessarily represent IMF views or IMF policy. The views expressed herein should be attributed to the authors and not to the IMF, its Executive Board, or its management. Staff Discussion Notes are published to elicit comments and to further debate.

JEL Classification Numbers: D63, D31, 015, H23,

Keywords: Inequality, Gini coefficient, cross-country analysis

Author's E-mail Addresses: EDablanorris@imf.org; KKochhar@imf.org; FRicka@imf.org; NSuphaphiphat@imf.org; ETsounta@imf.org

\footnotetext{
${ }^{1}$ Frank Wallace and Zhongxia Zhang provided excellent research assistance. We also thank Ricardo Reinoso and Christiana Weekes for editorial assistance.
} 


\section{CONTENTS}

EXECUTIVE SUMMARY

II. MACROECONOMIC CONSEQUENCES: WHY WE CARE

III. STYLIZED FACTS: WHAT DO WE KNOW ABOUT INEQUALITY OF OUTCOMES AND OPPORTUNITIES? $\underline{9}$

IV. INEQUALITY DRIVERS $\underline{18}$

A. Factors Driving Higher Income Inequality ___

B. Empirical Analysis _ $\underline{22}$

V. POLICY DISCUSSION AND FINAL REMARKS__ $\underline{\mathbf{3 0}}$

ANNEX I. DEFINITIONS AND SOURCES OF VARIABLES ___ $\underline{33}$

\section{FIGURES}

1. Income Inequality and Social Mobility __ $\underline{8}$

2. Global Inequality and Distribution of Income __

3. Change in Net Gini Index, 1990-2012 _ 11

4. Change in Gross Gini and Income Decile___ 12

5. Top 1\% Income Share __ 13

6. Estimated Corporate Profits__

7. Change in Income Share, 1990-2009__

8. Disconnect: Real Average Wage and Productivity___ 14

9. Poverty Rates by Regions __ 15

10. Top 1\% and Bottom 90\% Wealth Distribution, 1980-2010__ 15

11. Wealth and Income Inequality in Advanced and Emerging Market Economies, $2000 \_16$

12. Inequalities in Health by Quintile, 2010-12 __ 17

13. Education Gini and Outcomes by Income Decile __ 17

14. Financial Inclusion in Advanced and Developing Countries __

15. Technological Progress and Skill Premium in OECD Countries _

16. Trade and Financial Openness __ 20

17. Union Rate by Country Group __ 21

18. Change in Top Tax Rate and Top 1 Percent Income Share __ $\underline{22}$

19. Impact of Change in Financial Deepening on Inequality ___ $\underline{23}$

20. Decomposition of the Change in Market (Gross) Income Inequality __ 27

21. Change in Income Share of the Bottom 10 Percent and Middle Decile__ $\underline{28}$

\section{TABLES}

1. Regression Results of Growth Drivers __

2. Regression Results of Inequality Drivers __ $\underline{25}$

3. Regression Results on Determinants of Poverty Change___ 29

\section{BOXES}

1. Assessing the Drivers of Income Inequality Around the World __ 24

2. Drivers of Poverty _ $\underline{29}$ 


\section{EXECUTIVE SUMMARY}

"We should measure the health of our society not at its apex, but at its base." Andrew Jackson

Widening income inequality is the defining challenge of our time. In advanced economies, the gap between the rich and poor is at its highest level in decades. Inequality trends have been more mixed in emerging markets and developing countries (EMDCsf), with some countries experiencing declining inequality, but pervasive inequities in access to education, health care, and finance remain. Not surprisingly then, the extent of inequality, its drivers, and what to do about it have become some of the most hotly debated issues by policymakers and researchers alike. Against this background, the objective of this paper is two-fold.

First, we show why policymakers need to focus on the poor and the middle class. Earlier IMF work has shown that income inequality matters for growth and its sustainability. Our analysis suggests that the income distribution itself matters for growth as well. Specifically, if the income share of the top 20 percent (the rich) increases, then GDP growth actually declines over the medium term, suggesting that the benefits do not trickle down. In contrast, an increase in the income share of the bottom 20 percent (the poor) is associated with higher GDP growth. The poor and the middle class matter the most for growth via a number of interrelated economic, social, and political channels.

Second, we investigate what explains the divergent trends in inequality developments across advanced economies and EMDCs, with a particular focus on the poor and the middle class. While most existing studies have focused on advanced countries and looked at the drivers of the Gini coefficient and the income of the rich, this study explores a more diverse group of countries and pays particular attention to the income shares of the poor and the middle class-the main engines of growth. Our analysis suggests that

- Technological progress and the resulting rise in the skill premium (positives for growth and productivity) and the decline of some labor market institutions have contributed to inequality in both advanced economies and EMDCs. Globalization has played a smaller but reinforcing role. Interestingly, we find that rising skill premium is associated with widening income disparities in advanced countries, while financial deepening is associated with rising inequality in EMDCs, suggesting scope for policies that promote financial inclusion.

- Policies that focus on the poor and the middle class can mitigate inequality. Irrespective of the level of economic development, better access to education and health care and well-targeted social policies, while ensuring that labor market institutions do not excessively penalize the poor, can help raise the income share for the poor and the middle class.

- There is no one-size-fits-all approach to tackling inequality. The nature of appropriate policies depends on the underlying drivers and country-specific policy and institutional settings. In advanced economies, policies should focus on reforms to increase human capital and skills, coupled with making tax systems more progressive. In EMDCs, ensuring financial deepening is accompanied with greater financial inclusion and creating incentives for lowering informality would be important. More generally, complementarities between growth and income equality objectives suggest that policies aimed at raising average living standards can also influence the distribution of income and ensure a more inclusive prosperity. 


\section{CONTEXT}

1. Rising inequality is a widespread concern. Inequality within most advanced and emerging markets and developing countries (EMDCs) has increased, a phenomenon that has received considerable attention-President Obama called widening income inequality the "defining challenge of our time." A recent Pew Research Center (PRC 2014) survey found that the gap between the rich and the poor is considered a major challenge by more than 60 percent of respondents worldwide, and Pope Francis has spoken out against the "economy of exclusion." Indeed, the PRC survey found that while education and working hard were seen as important for getting ahead, knowing the right persons and belonging to a wealthy family were also critical, suggesting potential major hurdles to social mobility. Not surprisingly then, the extent of inequality, its drivers, and what to do about it have become some of the most hotly debated issues by policymakers and researchers alike.

2. Why it matters. Equality, like fairness, is an important value in most societies. Irrespective of ideology, culture, and religion, people care about inequality. Inequality can be a signal of lack of income mobility and opportunity - a reflection of persistent disadvantage for particular segments of the society. Widening inequality also has significant implications for growth and macroeconomic stability, it can concentrate political and decision making power in the hands of a few, lead to a suboptimal use of human resources, cause investment-reducing political and economic instability, and raise crisis risk. The economic and social fallout from the global financial crisis and the resultant headwinds to global growth and employment have heightened the attention to rising income inequality.

3. This note. The objective of the note is two-fold. First, it shows why policymakers need to focus on the poor and the middle class. Building on earlier IMF work which has shown that income inequality matters for growth, we show that the income distribution itself matters for growth as well. In particular, our findings suggest that raising the income share of the poor and ensuring that there is no hollowing-out of the middle class is good for growth through a number of interrelated economic, social, and political channels. Second, we investigate what explains the divergent trends in inequality developments across advanced economies and EMDCs, with a particular focus on the poor and the middle class. In that context, we are filling a gap in the literature since existing studies typically focus only on advanced economies or a smaller sample of EMDCs. This approach allows us to suggest policy implications depending on the underlying drivers, and country-specific policy and institutional settings.

4. Roadmap. Section II provides an overview of the macroeconomic implications of high inequality of outcomes and opportunities and shows why policymakers' focus on the income shares of poor and the middle class can prove growth-enhancing. Section III provides a rich documentation of recent trends in both monetary and nonmonetary indicators of inequality across advanced economies and EMDCs, while Section IV investigates the drivers of the rise in inequality, including from an empirical perspective. Section $V$ concludes and discusses policy implications. 


\section{MACROECONOMIC CONSEQUENCES: WHY WE CARE}

5. Outcomes and opportunities. The discourse on inequality often makes a distinction between inequality of outcomes (as measured by income, wealth, or expenditure) and inequality of opportunities - attributed to differences in circumstances beyond the individual's control, such as gender, ethnicity, location of birth, or family background. Inequality of outcomes arises from a combination of differences in opportunities and individual's efforts and talent. At the same time, it is not easy to separate effort from opportunity, especially in an intergenerational context. For instance, parental income, resulting from their own effort, determines the opportunity of their children to obtain an education. It is in this spirit that Rawls (1971) argued that the distribution of opportunities and of outcomes are equally important and informative to understand the nature and extent of inequality around the world.

6. Is inequality a necessary evil? Some degree of inequality may not be a problem insofar as it provides the incentives for people to excel, compete, save, and invest to move ahead in life. For example, returns to education and differentiation in labor earnings can spur human capital accumulation and economic growth, despite being associated with higher income inequality. Inequality can also influence growth positively by providing incentives for innovation and entrepreneurship (Lazear and Rosen 1981), and, perhaps especially relevant for developing countries, by allowing at least a few individuals to accumulate the minimum needed to start businesses and get a good education (Barro 2000).

7. Why is rising inequality a concern? High and sustained levels of inequality, especially inequality of opportunity can entail large social costs. Entrenched inequality of outcomes can significantly undermine individuals' educational and occupational choices. Further, inequality of outcomes does not generate the "right" incentives if it rests on rents (Stiglitz 2012). In that event, individuals have an incentive to divert their efforts toward securing favored treatment and protection, resulting in resource misallocation, corruption, and nepotism, with attendant adverse social and economic consequences. In particular, citizens can lose confidence in institutions, eroding social cohesion and confidence in the future.

8. Income distribution matters for growth. Previous IMF studies have found that income inequality (as measured by the Gini coefficient, which is 0 when everybody has the same income and 1 when one person has all the income) negatively affects growth and its sustainability (Ostry, Berg, and Tsangarides 2014; Berg and Ostry 2011). We build on this analysis by examining how individuals' income shares at various points in the distribution matter for growth drawing on a large sample of advanced economies and EMDCs (Table 1 ). ${ }^{2}$ A higher net Gini coefficient (a measure of

\footnotetext{
2 This analysis is based on a sample of 159 advanced, emerging, and developing economies for the period 19802012 using a simple growth model (with time and country fixed effects) in which growth depends on initial income (convergence hypothesis), lagged GDP growth, and inequality (as measured by net Gini or the income shares accruing to various quintiles) estimated using system GMM. Augmenting this model with standard growth determinants, such as human and physical capital, does not affect our main findings. See Annex for data sources.
} 
inequality that nets out taxes and transfers) is associated with lower output growth over the medium term, consistent with previous findings. More importantly, we find an inverse relationship between the income share accruing to the rich (top 20 percent) and economic growth. If the income share of the top 20 percent increases by 1 percentage point, GDP growth is actually 0.08 percentage point lower in the following five years, suggesting that the benefits do not trickle down. Instead, a similar increase in the income share of the bottom 20 percent (the poor) is associated with 0.38 percentage point higher growth. This positive relationship between disposable income shares and higher growth continues to hold for the second and third quintiles (the middle class). This result survives a variety of robustness checks, and is in line with recent findings for a smaller sample of advanced economies (OECD 2014). In the remainder of this section, we discuss potential channels for why higher income shares for the poor and the middle class are growth-enhancing.

\begin{tabular}{|c|c|c|c|c|c|c|}
\hline \multirow[b]{2}{*}{ Variables } & \multicolumn{6}{|c|}{ Dependent Variable: GDP Growth } \\
\hline & (1) & $(2)$ & (3) & (4) & $(5)$ & (6) \\
\hline Lagged GDP Growth & $\begin{array}{c}0.145^{* * *} \\
(0.033)\end{array}$ & $\begin{array}{c}0.112 * * * \\
(0.030)\end{array}$ & $\begin{array}{c}0.118^{* * *} \\
(0.031)\end{array}$ & $\begin{array}{c}0.113 * * * \\
(0.031)\end{array}$ & $\begin{array}{c}0.097 * * * \\
(0.030)\end{array}$ & $\begin{array}{c}0.114 * * * \\
(0.031)\end{array}$ \\
\hline GDP Per Capita Level (in logs) & $\begin{array}{c}-1.440^{* * * *} \\
(0.361)\end{array}$ & $\begin{array}{c}-2.198^{* * * *} \\
(0.302)\end{array}$ & $\begin{array}{c}-2.247 * * * \\
(0.307)\end{array}$ & $\begin{array}{c}-2.223^{* * *} \\
(0.308)\end{array}$ & $\begin{array}{c}-2.122 * * * \\
(0.304)\end{array}$ & $\begin{array}{c}-2.222 * * * \\
(0.307)\end{array}$ \\
\hline Net Gini & $\begin{array}{c}-0.0666^{*} \\
(0.034)\end{array}$ & & & & & \\
\hline 1st Quintile & & $\begin{array}{l}0.381 * * \\
(0.165)\end{array}$ & & & & \\
\hline 2nd Quintile & & & $\begin{array}{c}0.325^{* *} \\
(0.146)\end{array}$ & & & \\
\hline 3rd Quintile & & & & $\begin{array}{l}0.266^{*} \\
(0.152)\end{array}$ & & \\
\hline 4th Quintile & & & & & $\begin{array}{l}0.0596 \\
(0.180)\end{array}$ & \\
\hline 5th Quintile & & & & & & $\begin{array}{c}-0.0837 * \\
(0.044)\end{array}$ \\
\hline Constant & $\begin{array}{c}17.34 * * * \\
(3.225)\end{array}$ & $\begin{array}{c}18.82 * * * \\
(2.579)\end{array}$ & $\begin{array}{c}18.12 * * * \\
(2.713)\end{array}$ & $\begin{array}{c}17.45^{* * * *} \\
(3.058)\end{array}$ & $\begin{array}{c}19.41 * * * \\
(4.203)\end{array}$ & $\begin{array}{c}25.32 * * * * \\
(3.496)\end{array}$ \\
\hline Country Fixed Effects & Yes & Yes & Yes & Yes & Yes & Yes \\
\hline Time Dummies & Yes & Yes & Yes & Yes & Yes & Yes \\
\hline \#. of Observations & 733 & 455 & 455 & 455 & 455 & 455 \\
\hline \#. of Countries & 159 & 156 & 156 & 156 & 156 & 156 \\
\hline $\begin{array}{l}\text { Source: Solt Database; World Bar } \\
\text { calculations. } \\
\text { Note: Standard errors in parenth } \\
\text { which instruments potentially en } \\
\text { differences. The regressions inclu } \\
\text { invariant omitted-variable bias a } \\
\text { otherwise captured by the explar }\end{array}$ & $\begin{array}{l}\text { k; UNU-WIL } \\
\text { ses, * } \mathrm{p}<0 \text {. } \\
\text { logenous ri } \\
\text { de country } \\
\text { d global sh } \\
\text { atory variab }\end{array}$ & $\begin{array}{l}\text { ER World } \\
1 ;{ }^{* *} \mathrm{p}<0.0 \\
\text { ght-hand-s } \\
\text { and time di } \\
\text { ocks, which } \\
\text { les. }\end{array}$ & $\begin{array}{l}\text { ncome Ineq } \\
5 ;{ }^{* * *} p<0.0 \\
\text { de variables } \\
\text { immies to re } \\
\text { might affec }\end{array}$ & $\begin{array}{l}\text { Uality Datal } \\
\text { 1. Estimate } \\
\text { s using lagg } \\
\text { espectively } \\
\text { t aggregate }\end{array}$ & $\begin{array}{l}\text { oase; and IN } \\
d \text { using syst } \\
\text { ed values a } \\
\text { control for } t \\
\text { growth bu }\end{array}$ & $\begin{array}{l}\text { MF staff } \\
\text { tem GMM, } \\
\text { nd first } \\
\text { time- } \\
\text { it are not }\end{array}$ \\
\hline
\end{tabular}




\section{Inequality affects growth drivers.}

Why would widening income disparities matter for growth? Higher inequality lowers growth by depriving the ability of lower-income households to stay healthy and accumulate physical and human capital (Galor and Moav 2004; Aghion, Caroli, and Garcia-Penalosa 1999). For instance, it can lead to underinvestment in education as poor children end up in lower-quality schools and are less able to go on to college. ${ }^{3}$ As a result, labor productivity could be lower than it would have been in a more equitable world (Stiglitz 2012). In the same vein, Corak (2013) finds that countries with higher levels of income inequality tend to have lower levels of mobility between

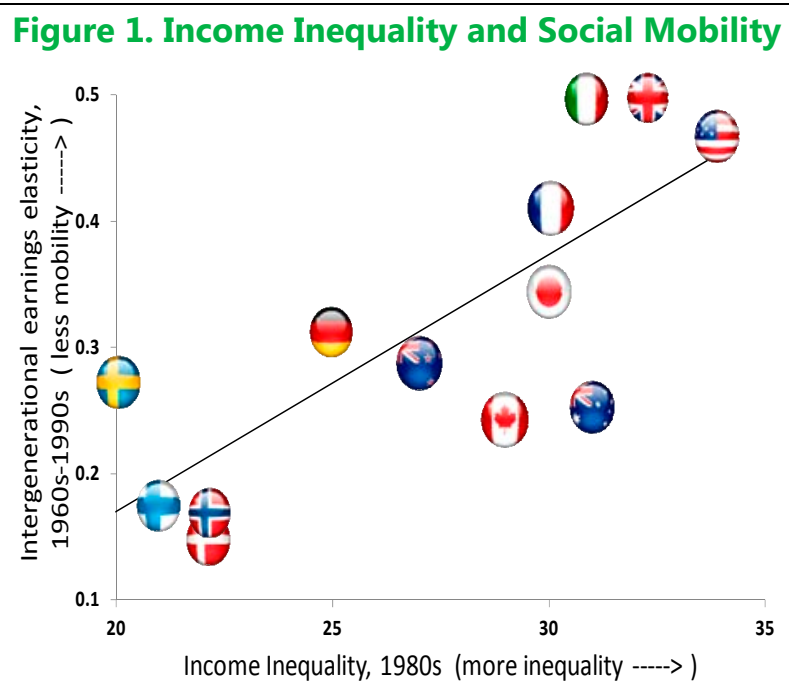

Sources: Corak (2013); Organisation of Economic Cooperation and Development; and IMF staff calculations. generations, with parent's earnings being a more important determinant of children's earnings (Figure 1). Increasing concentration of incomes could also reduce aggregate demand and undermine growth, because the wealthy spend a lower fraction of their incomes than middle- and lower-income groups. ${ }^{4}$

\section{Inequality dampens investment, and hence growth, by fueling economic, financial, and} political instability.

- Financial crises. A growing body of evidence suggests that rising influence of the rich and stagnant incomes of the poor and middle class have a causal effect on crises, and thus directly hurt short- and long-term growth. ${ }^{5}$ In particular, studies have argued that a prolonged period of higher inequality in advanced economies was associated with the global financial crisis by intensifying leverage, overextension of credit, and a relaxation in mortgage-underwriting standards (Rajan 2010), and allowing lobbyists to push for financial deregulation (Acemoglu 2011).

- Global imbalances. Higher top income shares coupled with financial liberalization, which itself could be a policy response to rising income inequality, are associated with substantially larger

\footnotetext{
${ }^{3}$ Widening income disparities can depress skills development among individuals with poorer parental education background, both in terms of the quantity of education attained (for example, years of schooling) and its quality (that is, skill proficiency). Educational outcomes of individuals from richer backgrounds, however, are not affected by inequality (Cingano 2014).

${ }^{4}$ See Carvalho and Rezai (2014) for a discussion of the empirical and theoretical underpinnings of this assertion.

${ }^{5}$ In a theoretical setting, Kumhof and Ranciere (2010) and Kumhof and others (2012) show that rising inequality enables investors to increase their holding of financial assets backed by loans to workers, resulting in rising debt-toincome ratios and thus financial fragility. The latter can eventually lead to a financial crisis.
} 
external deficits (Kumholf and others 2012). Such large global imbalances can be challenging for macroeconomic and/or financial stability, and thus growth (Bernanke 2011).

- Conflicts. Extreme inequality may damage trust and social cohesion and thus is also associated with conflicts, which discourage investment. Conflicts are particularly prevalent in the management of common resources where, for example, inequality makes resolving disputes more difficult; see, for example, Bardhan (2005). More broadly, inequality affects the economics of conflict, as it may intensify the grievances felt by certain groups or can reduce the opportunity costs of initiating and joining a violent conflict (Lichbach 1989).

11. Inequality can lead to policies that hurt growth. In addition to affecting growth drivers, inequality could result in poor public policy choices. For example, it can lead to a backlash against growth-enhancing economic liberalization and fuel protectionist pressures against globalization and market-oriented reforms (Claessens and Perotti 2007). At the same time, enhanced power by the elite could result in a more limited provision of public goods that boost productivity and growth, and which disproportionately benefit the poor (Putnam 2000; Bourguignon and Dessus 2009).

12. Inequality hampers poverty reduction. Income inequality affects the pace at which growth enables poverty reduction (Ravallion 2004). Growth is less efficient in lowering poverty in countries with high initial levels of inequality or in which the distributional pattern of growth favors the nonpoor. Moreover, to the extent that economies are periodically subject to shocks of various kinds that undermine growth, higher inequality makes a greater proportion of the population vulnerable to poverty.

\section{STYLIZED FACTS: WHAT DO WE KNOW ABOUT INEQUALITY OF OUTCOMES AND OPPORTUNITIES?}

13. Measuring inequality. Income inequality - the most widely cited measure of inequality of outcomes-is typically measured by the market (gross) and net (after tax and transfers from social insurance programs) Gini, and by tracking changes in the income shares of the population (for example, by decile/quintile). Information on the assets held by the wealthiest offers a complementary perspective on monetary inequality. Inequality of opportunities is often measured by tracking health, education and human development outcomes by income group, or by examining access to basic services and opportunities. In this section, we document recent trends in both monetary and nonmonetary indicators of inequality across a large sample of advanced and EMDCs.

\section{Inequality of outcomes: Income}

14. Global inequality remains high. Global inequality ranges from 0.55 to 0.70 depending on the measure used (Figure 2). The high level of global inequality reflects sizeable per capita income disparities across countries, which account for around three quarters of global inequality (Milanovic 2013). Some measures of global inequality exhibit a declining trend in the last few decades in response to rising incomes for those living in China and India, where hundreds of millions of people have been lifted out of poverty. However, other measures of global income inequality-adjusted for 
top incomes which tend to be underreported in most household surveys-appear to be broadly stable since the early 1990 s.

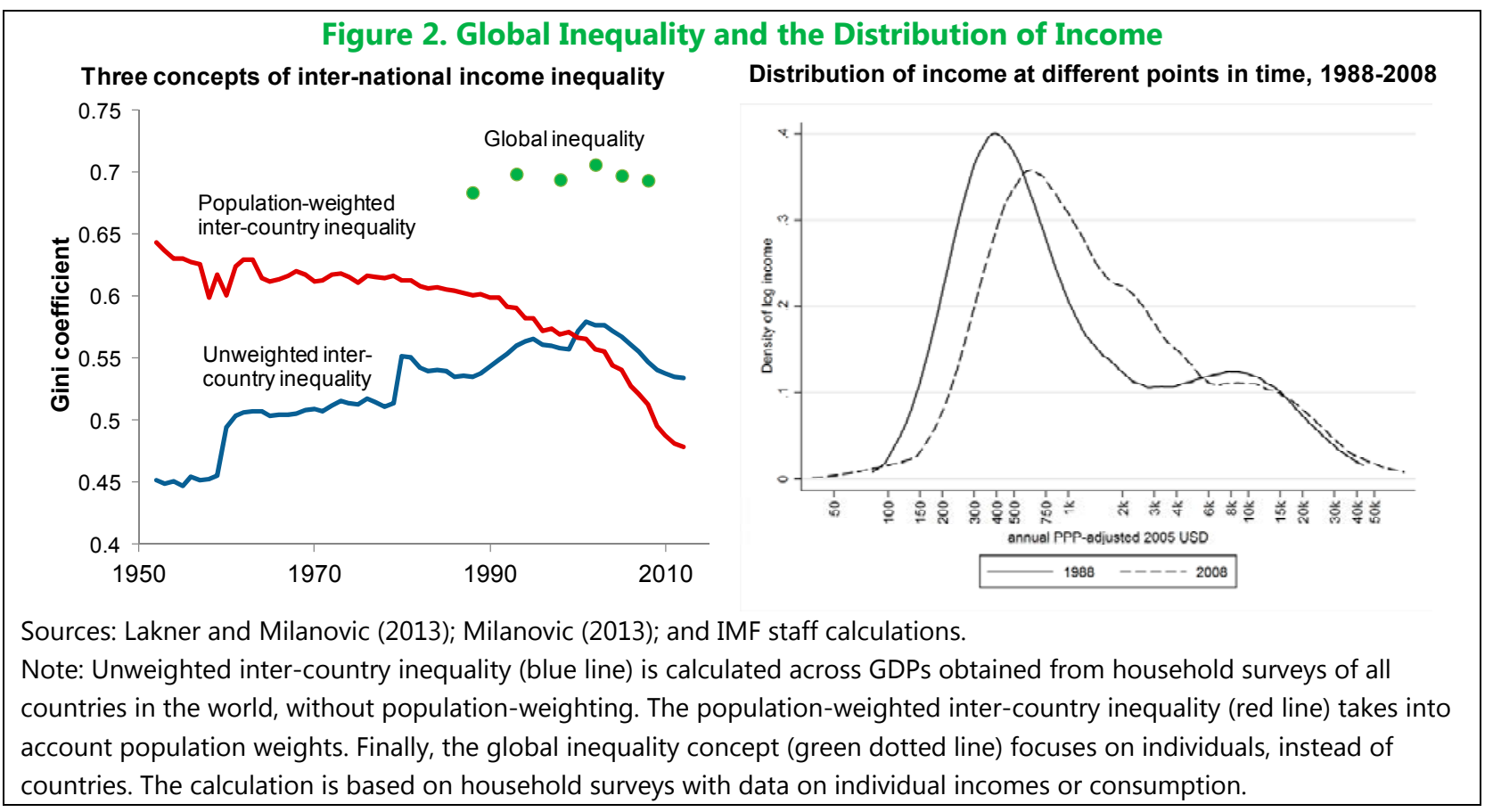

15. Globally, the middle class and the top 1 percent have experienced the largest gains.

Examining changes in real incomes between 1998 and 2008 at various percentiles of the global income distribution, Lakner and Milanovic (2013) show that the largest gains acrued for the global median income (50th percentile) earners and for the top 1 percent. This coincides with the rapid growth of the middle class in many emerging market economies, and the concentration of top earners in advanced economies, respectively. Moreover, income gains rapidly decrease after the 50th percentile and become stagnant around the 80th-90th global percentiles before shooting up for the global top 1 percent (Krugman 2014). In what follows, we focus on recent trends in withincountry inequality which drives these global developments.

16. Widening income inequality within countries. Measures of inequality based on Gini coefficients of gross and net incomes have increased substantially since 1990 in most of the developed world (Figure 3). Inequality, on average, has remained stable in EMDCs, albeit at a much higher level than observed in advanced economies. However, there are large disparities across EMDCs, with Asia and Eastern Europe experiencing marked increases in inequality, and countries in Latin America exhibiting notable declines (although the region remains the most unequal in the world). ${ }^{6}$ Redistribution, gauged by the difference between market and net inequality, played an important, albeit partial, role in cushioning market income inequality in advanced economies. During

\footnotetext{
${ }^{6}$ See Tsounta and Osueke (2014) and IMF (2014b) for a discussion of the declining inequality trends in Latin America and Middle East and North Africa regions, respectively.
} 
1990-2012, market inome inequality in advanced economies increased by an average of 51/4 Gini points compared to a 3 Gini point increase in the net Gini coefficient.

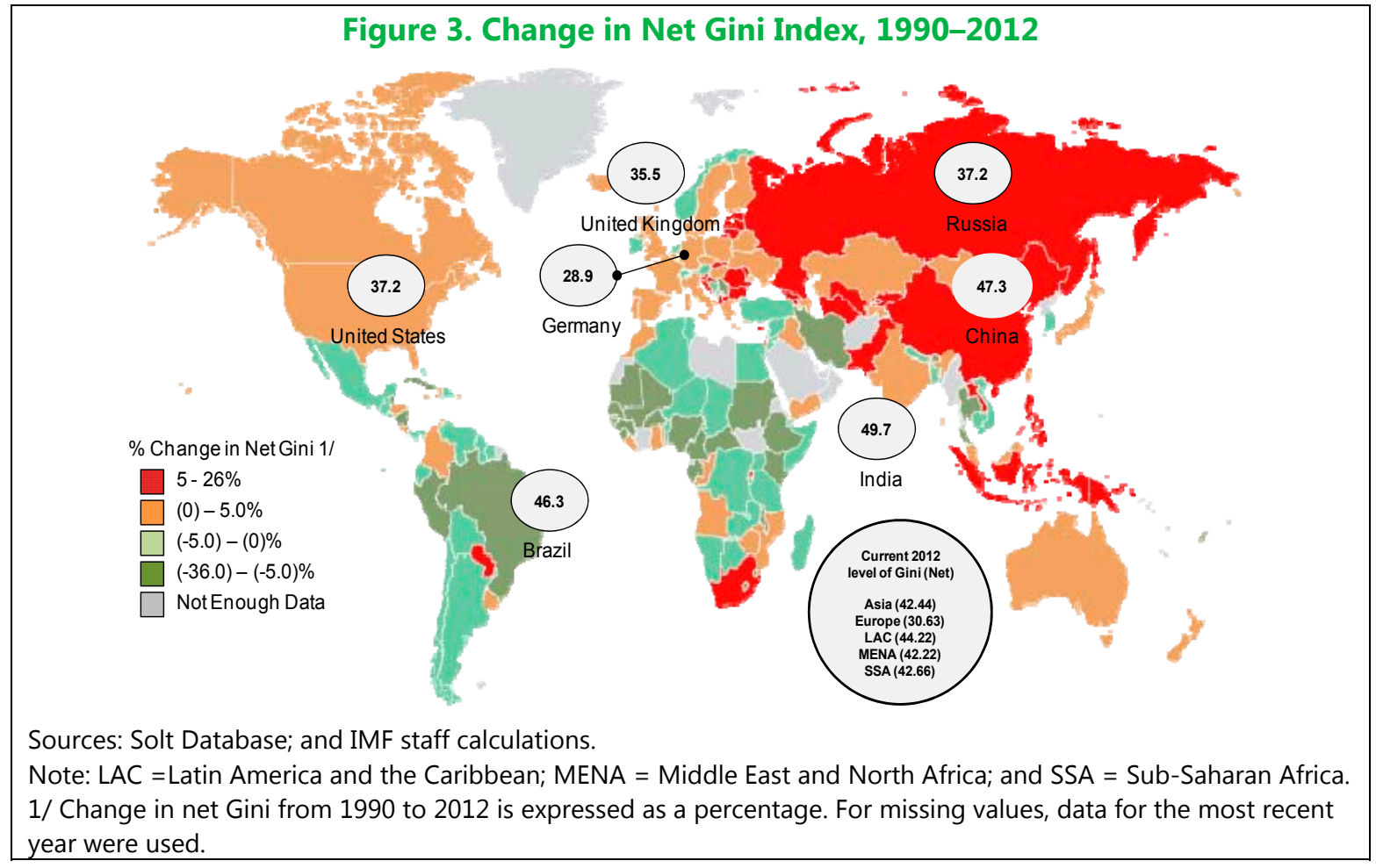

17. Income deciles under the microscope. Changes in income inequality across advanced economies and EMDCs have been driven by different developments in income shares by deciles. Figure 4 shows that rising income inequality (positive numbers on the vertical axes) in most advanced and many emerging market economies has been driven primarily by the growing income share of the top 10 percent (see also Piketty and Saez (2003) for the United States). Indeed, the top 10 percent now has an income close to nine times that of the bottom 10 percent. These effects have been magnified by the crisis (OECD 2014). The story is somewhat different in EMDCs. Rising inequality for this group of countries is primarily explained by a shift in incomes of the "upper middle class to the upper class" (for example, in China and South Africa). Figure 4 shows that in EMDCs with falling inequality (negative numbers on the vertical axis), the main beneficiaries (that is, with the largest increase in their income shares, shown on the horizontal axis) were those at both the bottom and the middle of the income distribution (for example, Peru and Brazil).

18. Top 1 percent on the rise. The top 1 percent now account for around 10 percent of total income in advanced economies. (Figure 5; Piketty and Saez 2011; Alvadero and others, 2013). While data on top income shares is scant for most EMDCs, available evidence suggests that the share of top incomes has risen in China and India. The growing share of the top 1 percent in advanced economies reflects both higher inequality in labor incomes as well as capital gains-returns from investments (Atkinson, Piketty, and Saez 2011). Indeed, about half of the income of the top 1 percent constitutes non-labor income compared with 30 percent for the top 10 percent as a whole. For instance, corporate profits have been translated into strikingly high executive salaries and 
bonuses, exacerbating income inequality (Brightman 2014), a pattern that is observed across both advanced and large emerging market economies (Figure 6).

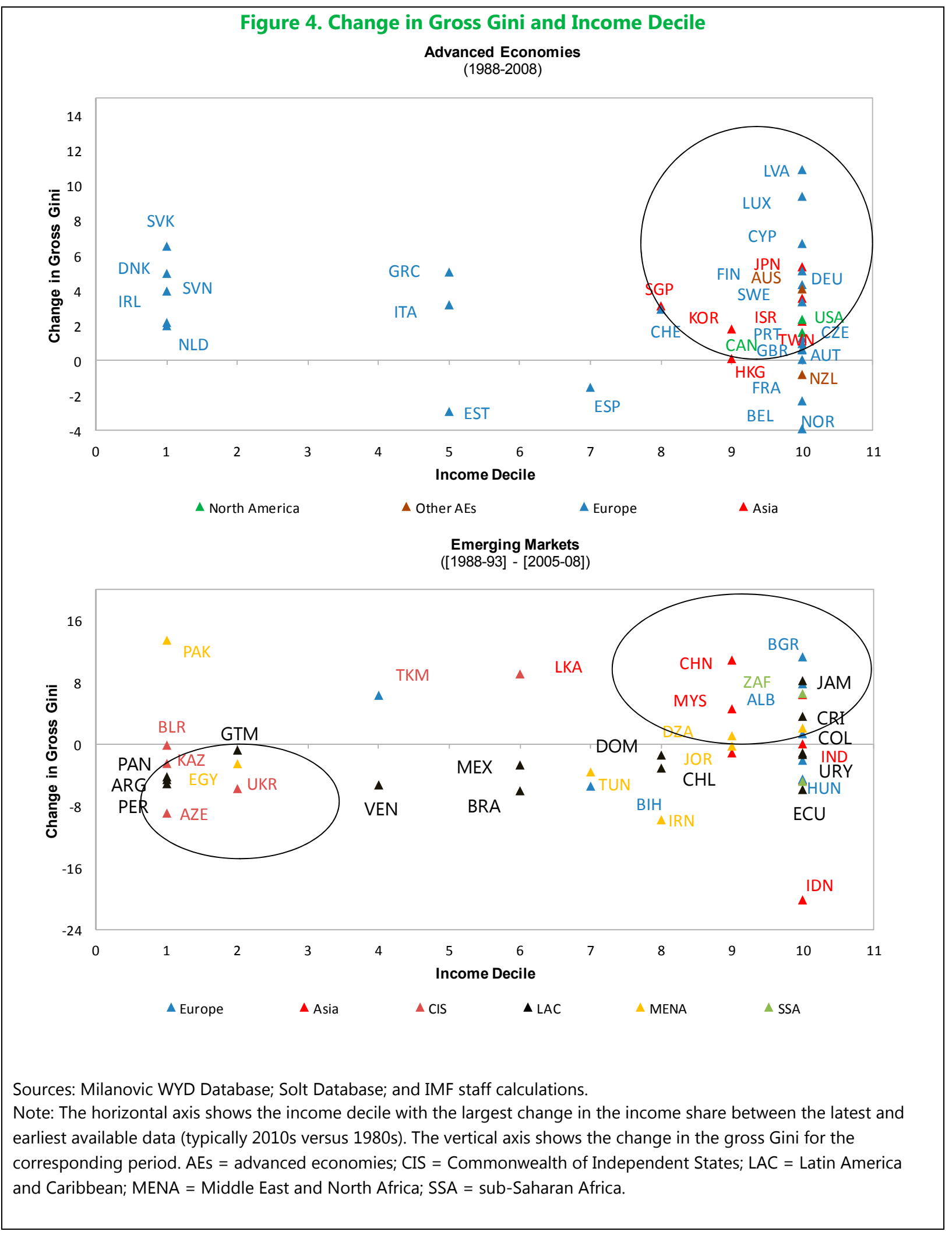




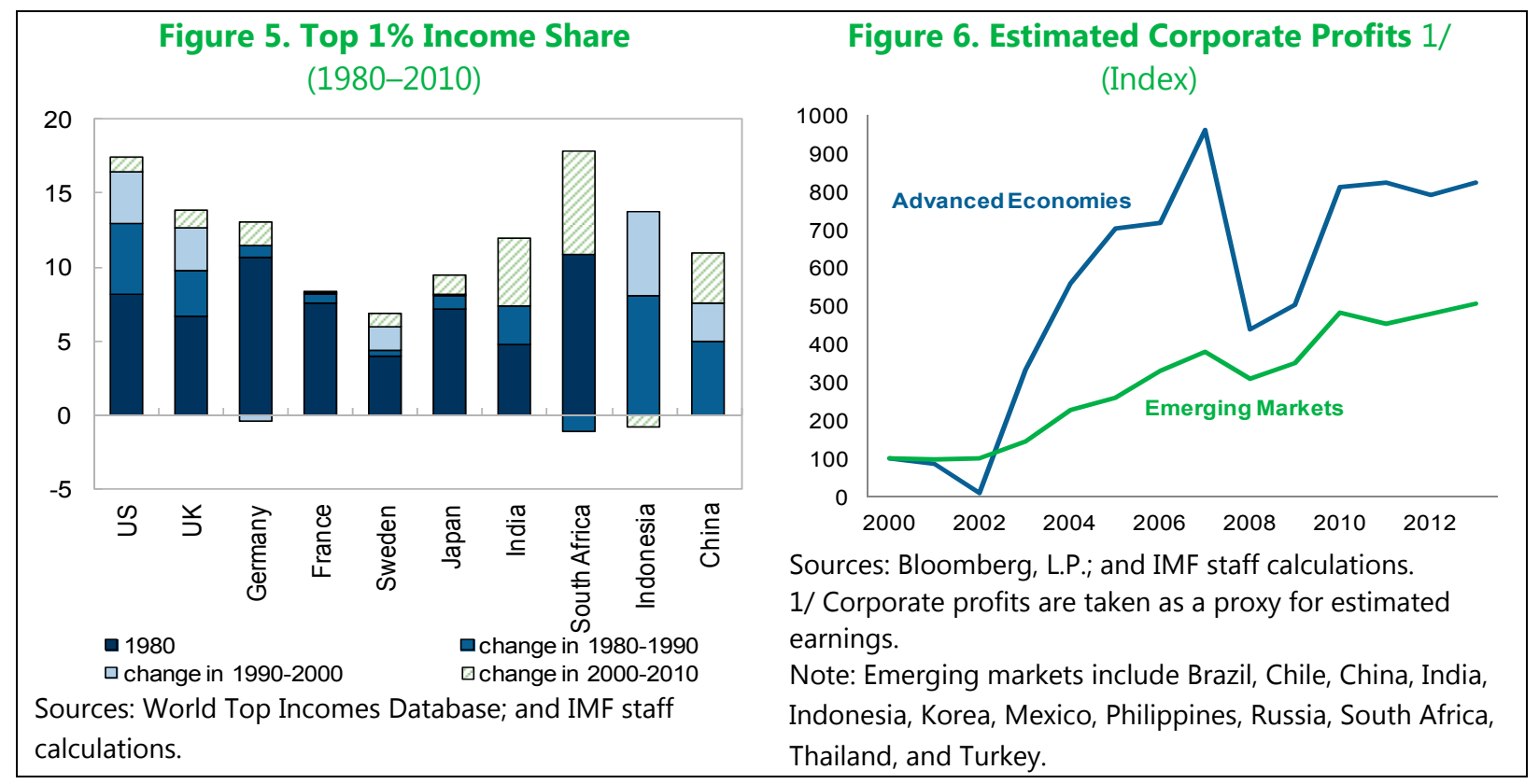

19. Middle class squeeze. A shift in the allocation of labor income towards the higher and lower ends of the distribution has resulted in a shrinkage of the income share accruing to the middle 20 percent in many advanced economies (Australia, Canada, and Sweden are important exceptions), and some large emerging market economies (Autor, Katz, and Kearney 2006; Figure 7). Indeed, pretax incomes of middle-class households in the United States, the United Kingdom, and Japan have experienced declining or stagnant growth rates in recent years. Additional pressures on the middle class reflect a declining share of labor income-the predominant source of income for the majority of households. Indeed, average wages have risen at a slower pace than

Figure 7. Change in Income Share, 1990-2009 (Average change, percent)

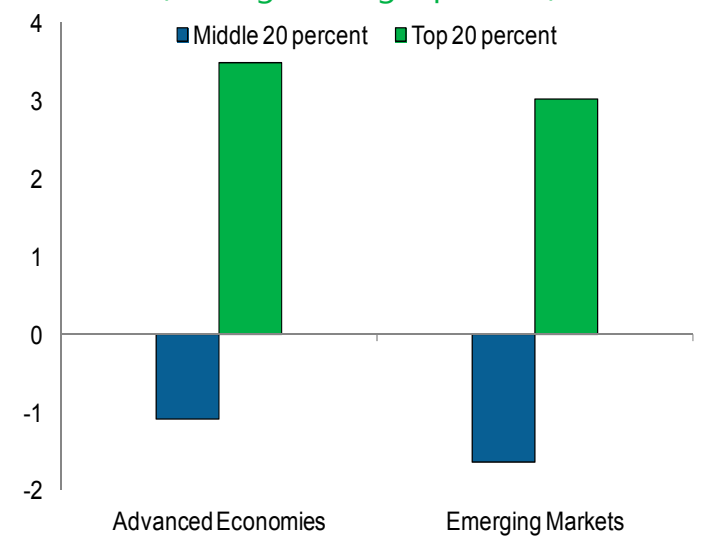

Sources: WDI database; and IMF staff calculations. Note: Emerging markets include Argentina, Brazil, China, India, Russia, and South Africa. productivity growth amid large economic rents (for example, high profitability and large increase in executive compensation) accruing to the top end of the income distribution (Figure 8). 
Figure 8. Disconnect: Real Average Wage and Productivity

- Labor Productivity-Real Average Wage Index

Selected Advanced Economies
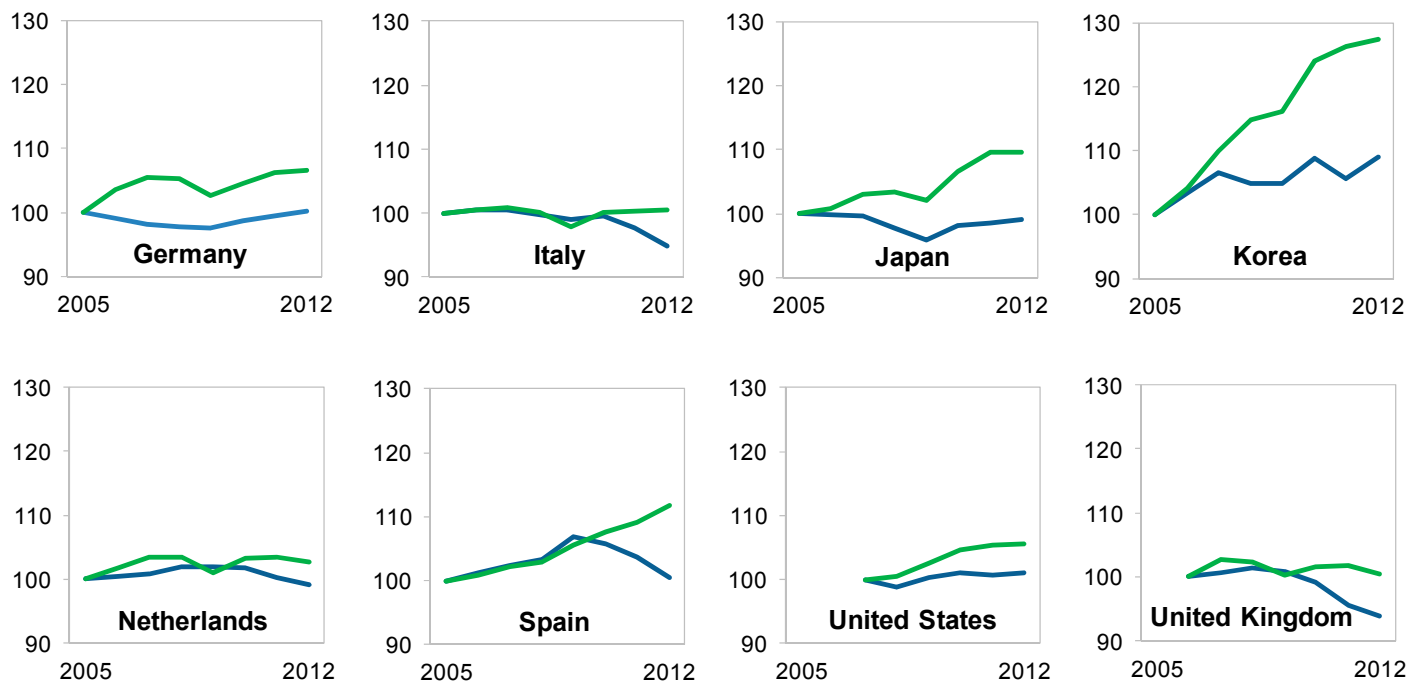

Selected Emerging Markets
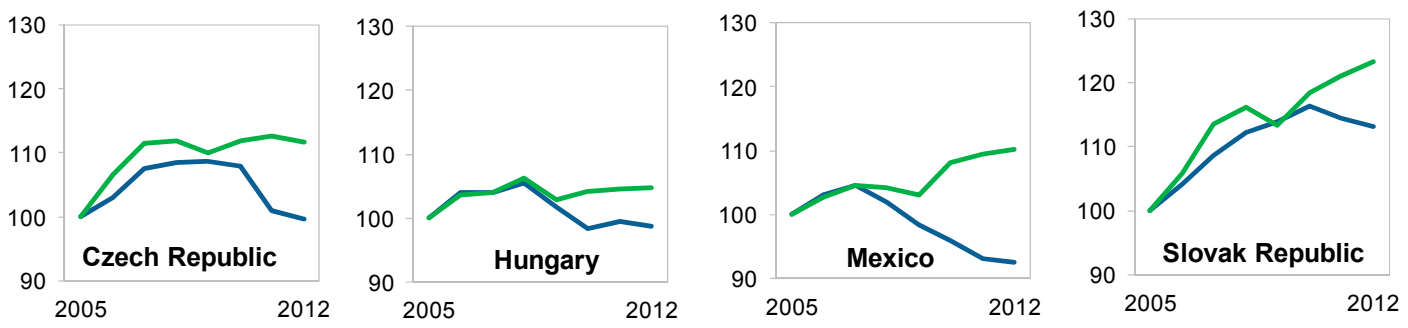

Sources: The Conference Board; International Labour Organization; and IMF staff calculations.

Note: Earnings reflect gross remuneration-in cash and in kind-paid to employees deflated by the consumer price index. Labor productivity represents real output per hours worked.

20. Sources behind the middle class squeeze vary. In advanced economies, the largest driver has been the declining share of middle-skilled occupations relative to low- and high-skilled occupations (Autor, Kerr, and Kugler 2007; Goos, Manning, and Salomons 2009). In EMDCs, the middle class squeeze in some countries reflects income polarization (Duclos, Esteban, and Ray 2004; Zhang and Kanbur, 2011). In China, for example, more than one-third of all wealth is concentrated in the top 1 percent, while the majority of the population remains poor despite strong economic growth (Hairong 2014). Widespread informality and persistently large geographical differences in economic performance have also played a particularly important role in shaping income inequality in EMDCs.

\section{Poverty has declined in many countries, but is on the rise in advanced economies. In} many EMDCs, poverty-measured in terms of the share of population living below a pre-defined poverty line-has declined, despite rising income inequality in some (Figure 9). In contrast, recent data suggest that poverty rose in advanced countries since the 1990s (OECD 2011). The ratio of the 
earnings of the 90th percentile to the earnings of the 10th percentile-another method of measuring inequality among the bottom 90 percent-grew in most advanced economies over the period between 1980 and 2011 (Autor 2014), particularly in the United States and the United Kingdom.

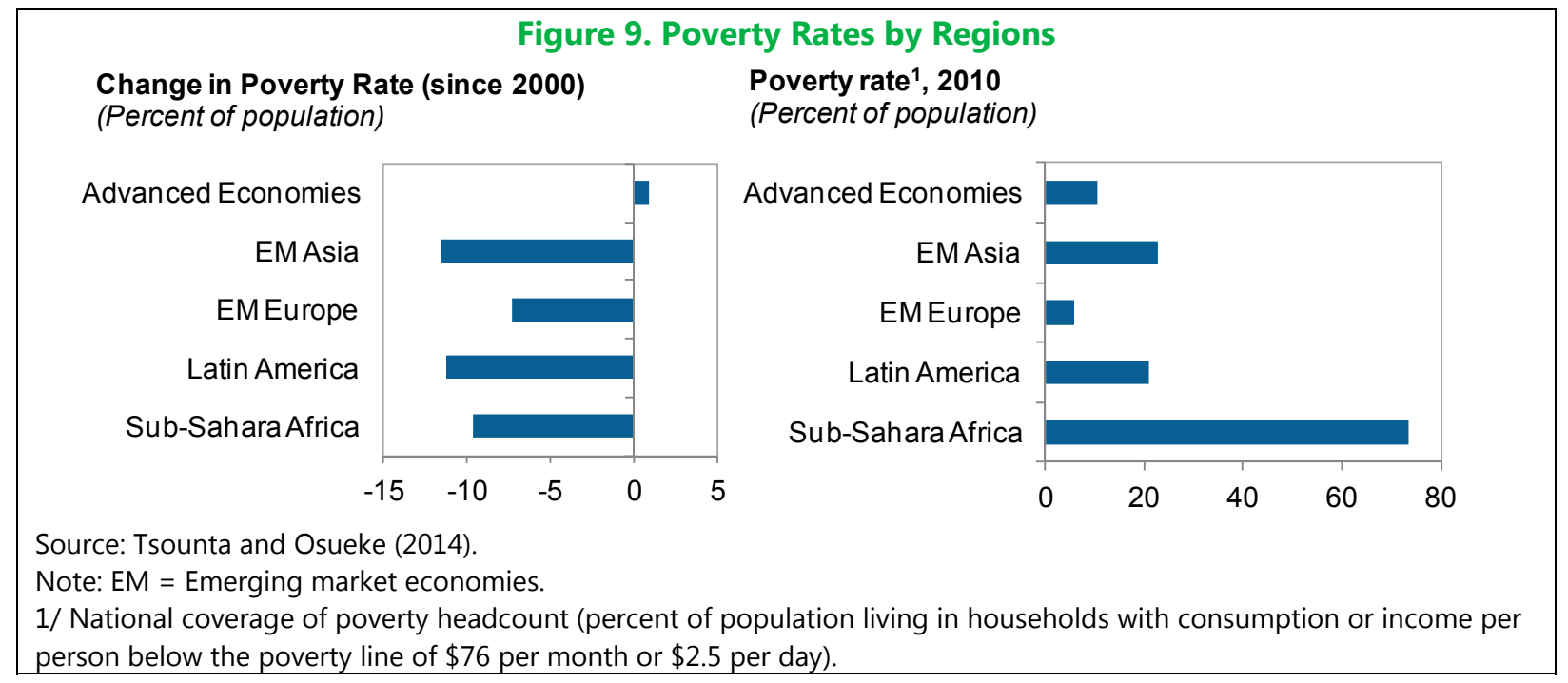

\section{Inequality of outcomes: Wealth}

22. Rising concentration of global wealth. Estimates suggest that almost half of the world's wealth is now owned by just 1 percent of the population, amounting to $\$ 110$ trillion -65 times the total wealth of the bottom half of the world's population (Credit Suisse 2013). ${ }^{7}$ For instance, a third of the total wealth in the United States is held by 1 percent of the population (Figure 10, left panel). In most countries with available data, the share held by the 1 percent wealthiest population is rising at the expense of the bottom 90 percent population (Figure 10, right panel).

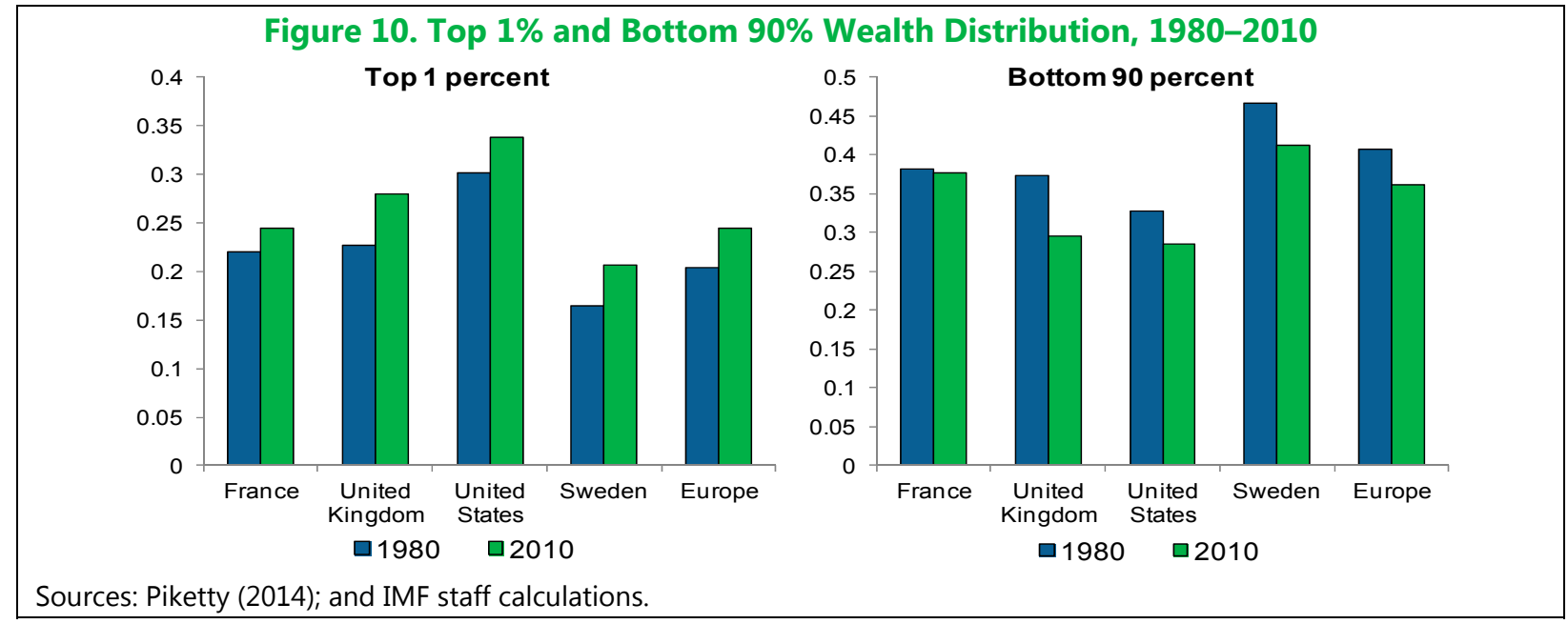

\footnotetext{
${ }^{7}$ Wealth or net worth is defined as the value of financial assets plus real assets (principally housing) owned by households, less their debts.
} 


\section{Inequality is more extreme in wealth}

than income. In both advanced economies and EMDCs, income Ginis, on average, are half the size of wealth Ginis (Figure 11). Possible explanations for the higher wealth Ginis include stagnant wage growth, which makes it difficult for middle- and lower-income workers to set aside money for saving, and a lower propensity to consume by the rich. ${ }^{8}$ While many studies suggest that growing wealth inequality in advanced economies is largely driven by rising wealth concentration at the top (Piketty 2014; Saez 2014), various explanations have been posited for the rise in EMDCs, ranging from wealth polarization between urban and rural areas in China to inequality among class and caste in India (Zhong and others 2010; Credit Suisse 2013).

\section{Inequality of Opportunity: Health Services}

24. Inequality in health outcomes is widespread in developing economies. While health outcomes are broadly similar across income groups in advanced countries, large disparities exist in EMDCs (Figure 12, left panel). For example, the infant mortality rate is twice as high in the poor than in the rich households (in terms of wealth) in emerging market economies. Similarly, female mortality rates tend to be disproportionately higher for lower-income groups.

\section{Inequality in health care access and use is more pervasive in developing countries.}

Commonly used indicators to gauge access and use of health care are generally favorable in advanced countries, irrespective of the income level of the population. For EMDCs, however, data on access to skilled health personnel for births suggest that there are large disparities in health access across income levels within developing countries, and to a lesser extent in emerging market countries (Figure 12, right panel). However, even in advanced economies, income inequality is increasingly being reflected in lower life expectancy. This is particularly striking in the United States, where income today is a stronger predictor of life expectancy than it was a generation ago (Murray, Lopez, and Alvarado 2013).

\footnotetext{
${ }^{8}$ Based on national balance sheets in nine advanced economies, Piketty and Zucman (2014) find that wealth-income ratios have doubled over the past 40 years.
} 


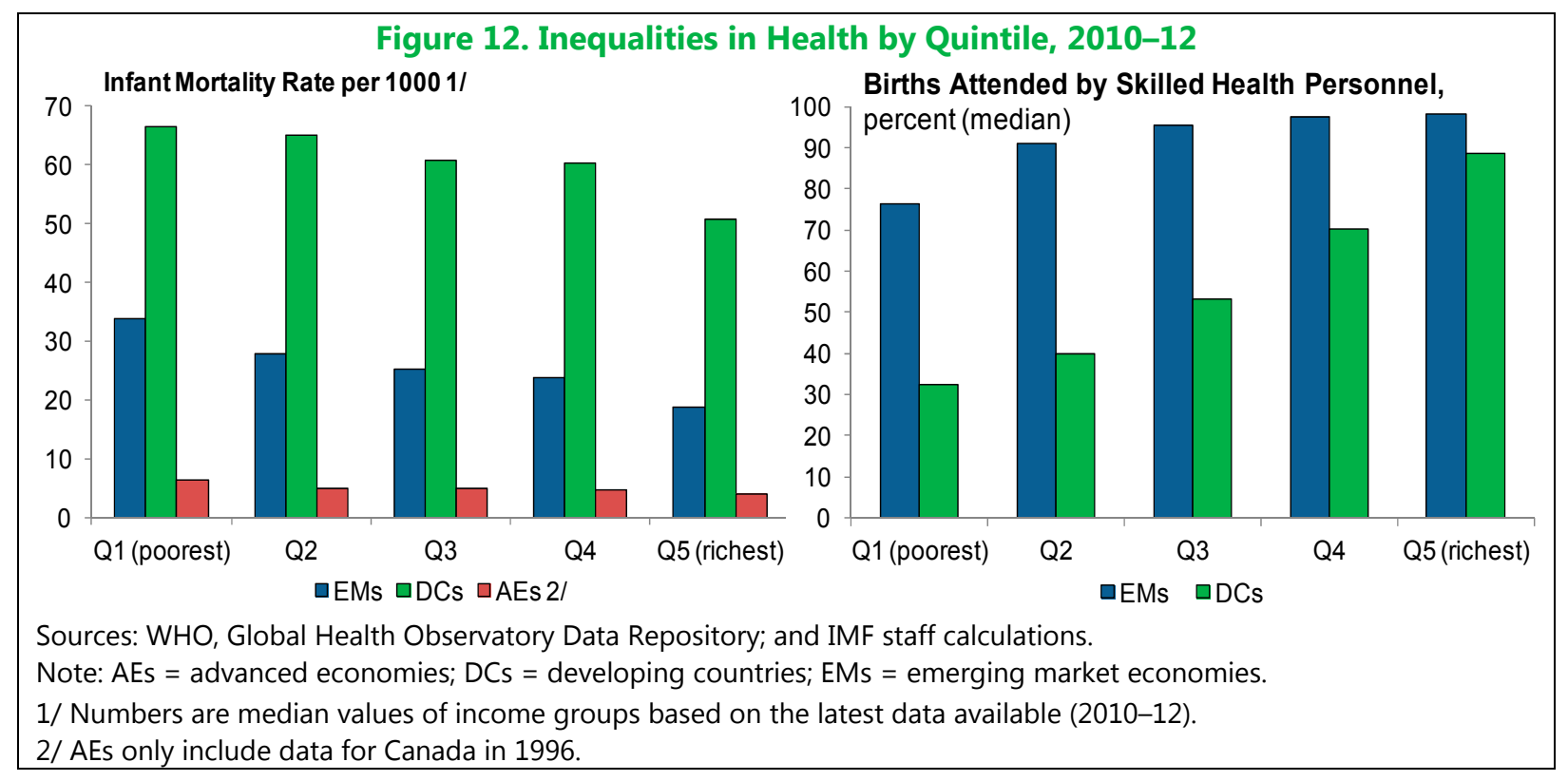

\section{Inequality of opportunity: Education}

26. Declining education inequality in EMDCs. The education Gini-a measure of the variation of average years of education for different income levels-has declined significantly in EMDCs, over the last 60 years (Figure 13, left panel). This is largely driven by improvements in access at the lowerend of the income distribution (Castello-Climent and Domenech 2014). Despite this improvement, education outcomes remain much worse for disadvantaged groups, partly because of pro-rich biases in the incidence of public spending (Dabla-Norris and Gradstein 2004). Indeed, almost 60 percent of the poorest youth population (aged 20-24 years) in sub-Sahara Africa has fewer than 4 years of schooling compared to 15 percent in the richest quintile (Figure 13, right panel). In contrast, education inequality, on average, is unchanged in most advanced economies over the last decade, although rising university costs have contributed to lower access to education by the poor in some countries. In the United States, for instance, college costs grew must faster than most households' income since 2001 (Federal Reserve 2014).

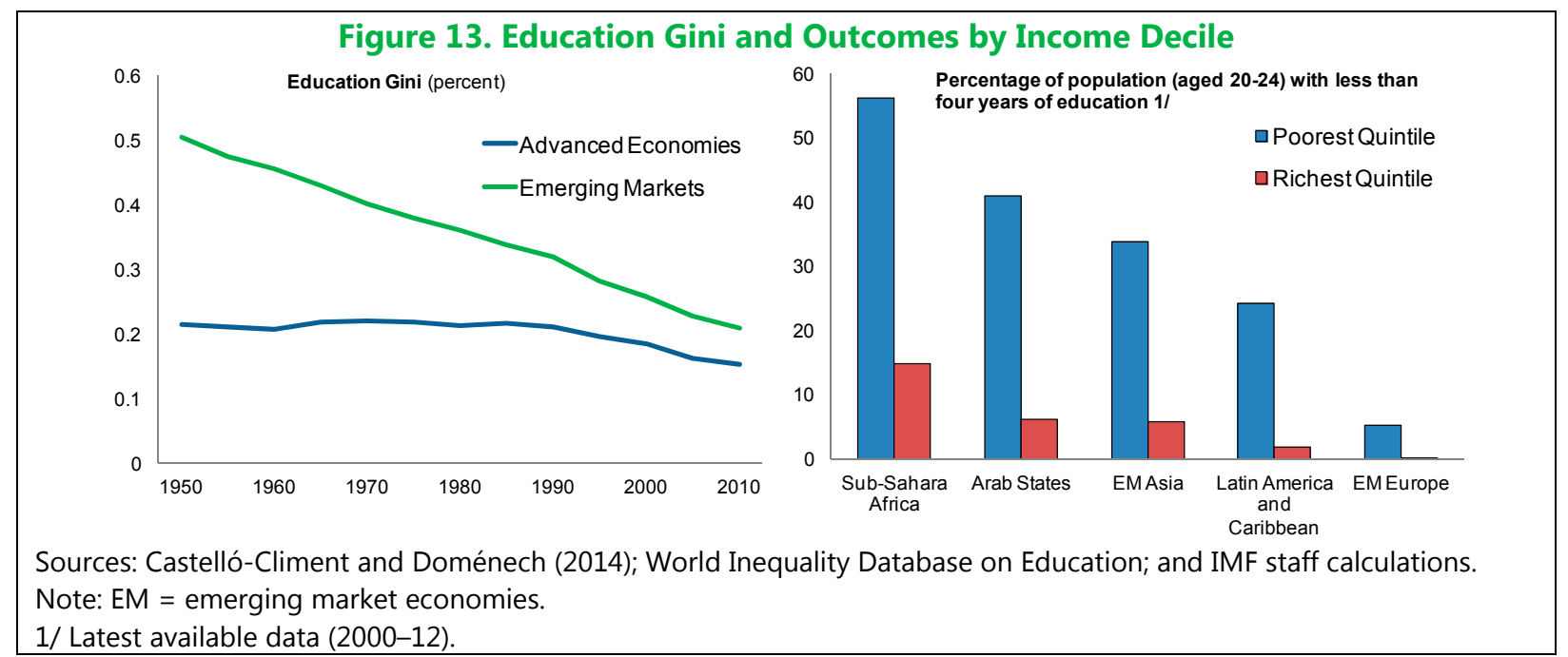




\section{Inequality of opportunities: Financial services}

27. Disparities in financial services access. There are large disparities in the use of financial services between advanced economies and EMDCs and across income levels within a country (Figure 14). More than 80 percent of adults in advanced economies have an account at a formal financial institution-twice more than in EMDCs. Within EMDCs, the share of adults with an account or a loan at a formal financial institution is largely skewed toward the top income earners. The rest rely on their own limited savings to invest in education or become entrepreneurs, suggesting that financial inequality and income inequality go hand in hand. In many EMDCs, low-income households and small-scale firms often face challenges in accessing financial services due to lack of financial knowledge, complicated processes, onerous paperwork, and other market failures. Moreover, available financial products tend to be more limited and relatively costly.

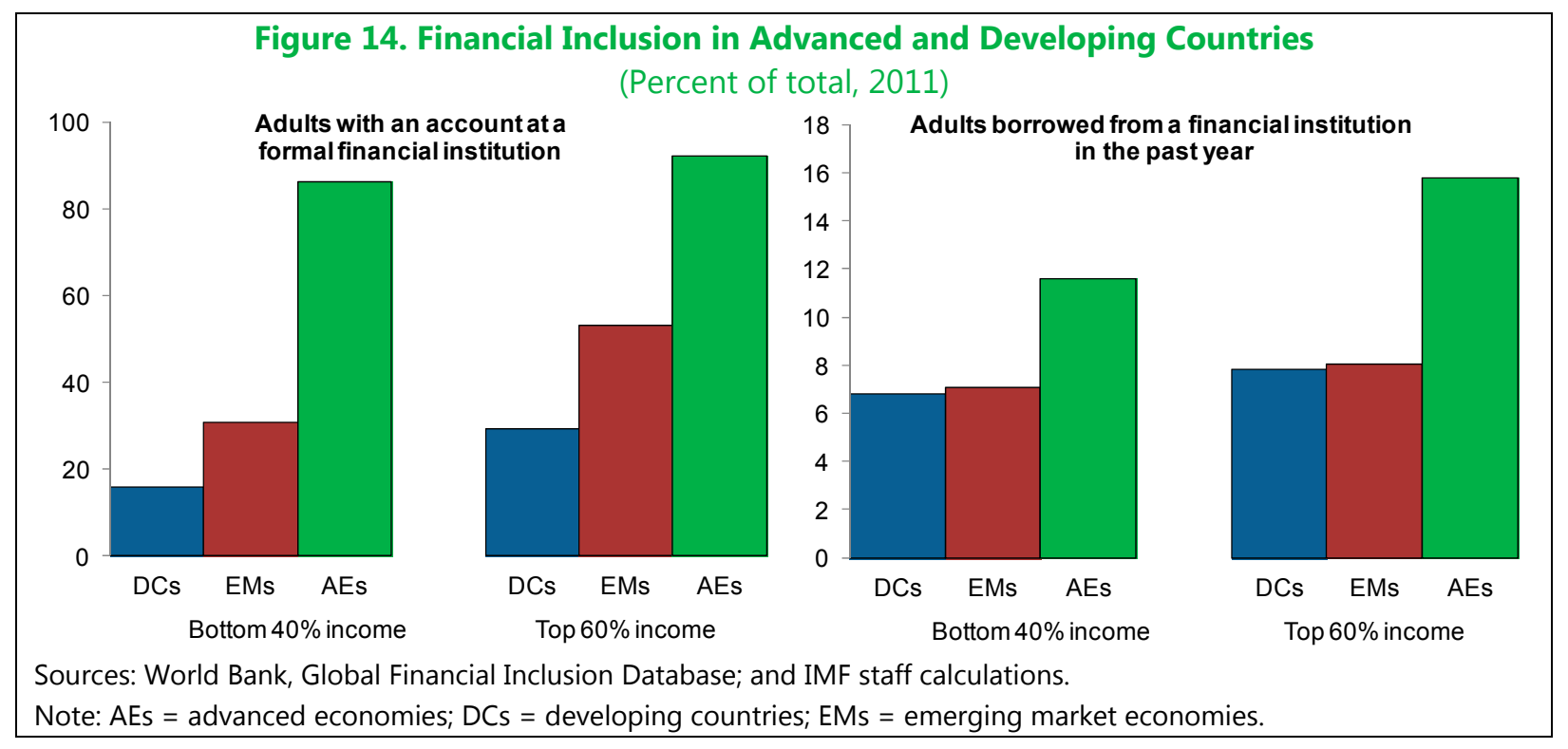

\section{INEQUALITY DRIVERS}

\section{A. Factors Driving Higher Income Inequality}

28. Global trends: the good side of the story. Over the past four decades, technology has reduced the costs of transportation, improved automation, and communication dramatically. New markets have opened, bringing growth opportunities in countries rich and poor alike, and hundreds of millions of people have been lifted out of poverty. However, inequality has also risen, possibly reflecting the fact that growth has been accompanied by skill-biased technological change, or because other aspects of the growth process have generated higher inequality. In this section, we discuss potential global and country-specific drivers of income inequality across countries.

29. Technological change. New information technology has led to improvements in productivity and well-being by leaps and bounds, but has also played a central role in driving up the 
skill premium, resulting in increased labor income inequality (Figure 15). This is because technological changes can disproportionately raise the demand for capital and skilled labor over low-skilled and unskilled labor by eliminating many jobs through automation or upgrading the skill level required to attain or keep those jobs (Card and Dinardo 2002; Acemoglu 1998). Indeed, technological advances have been found to have contributed the most to rising income inequality in OECD countries, accounting for nearly a third of the widening gap between the 90th and the 10th percentile earners over the last 25 years (OECD 2011). Evidence from larger emerging market economies also shows a similar trend of a growing earnings gap between high- and low-skilled workers despite a large rise in the supply of highly educated labor (which should reduce the gap).

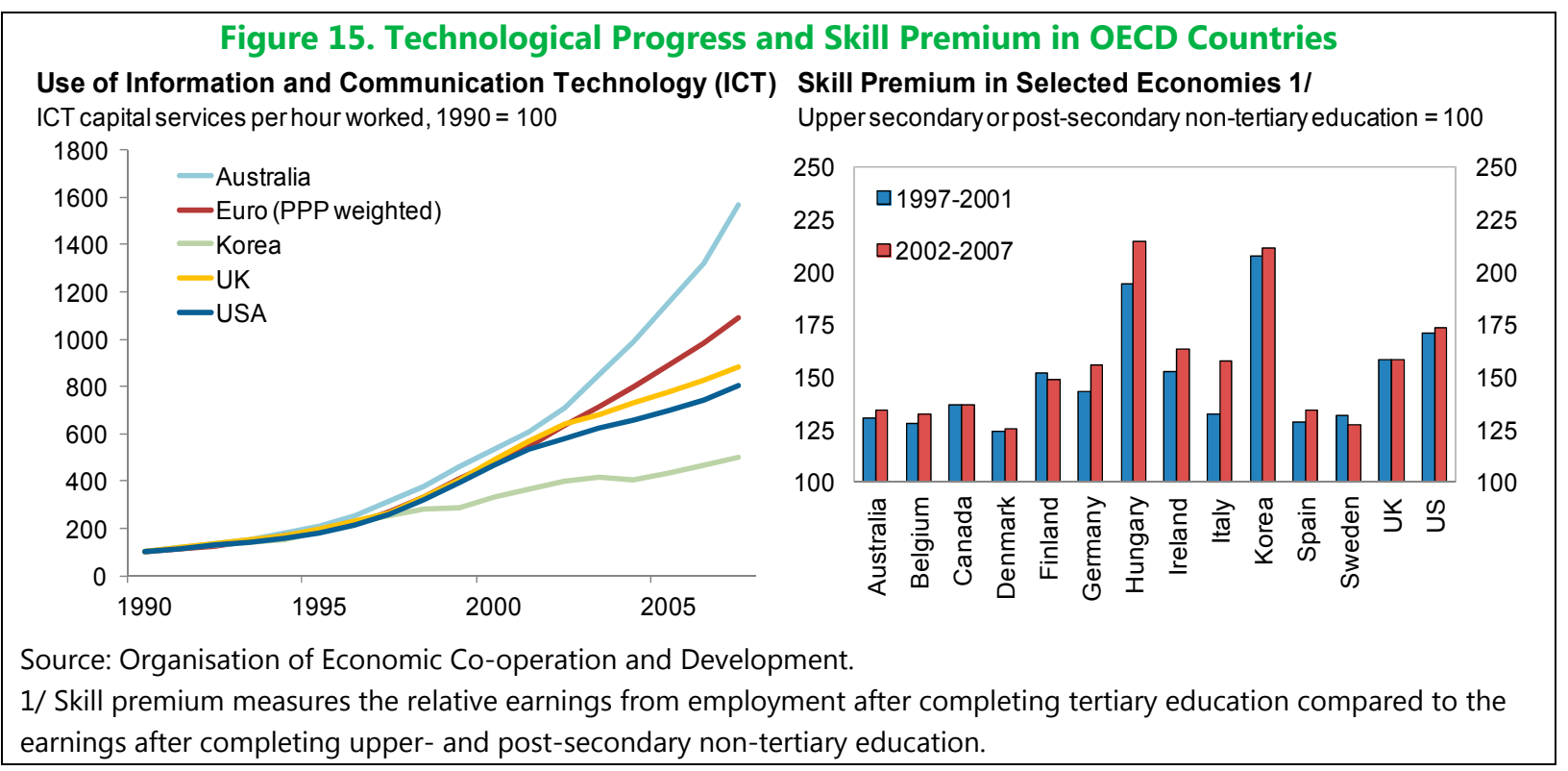

30. Trade globalization: two sides of a coin. Trade has been an engine for growth in many countries by promoting competitiveness and enhancing efficiency. Nonetheless, high trade and financial flows between countries, partly enabled by technological advances, are commonly cited as driving income inequality (Figure 16). In advanced economies, the ability of firms to adopt laborsaving technologies and offshoring has been cited as an important driver of the decline in manufacturing and rising skill premium (Feenstra and Hanson 1996, 1999, 2003). Trade openness could potentially have mixed effects on the wages of unskilled labor in advanced countries. It raises the skill premium, but could also increase real wages by lowering (import) prices (Munch and Skaksen 2009). At the same time, increased trade flows could lower income inequality in EMDCs by increasing demand and wages for abundant lower-skilled workers. Thus, disentangling the impact of trade on inequality is challenging as it depends on relative factor abundance and productivity differences across countries, and the extent to which individuals obtain income from wages or capital. 


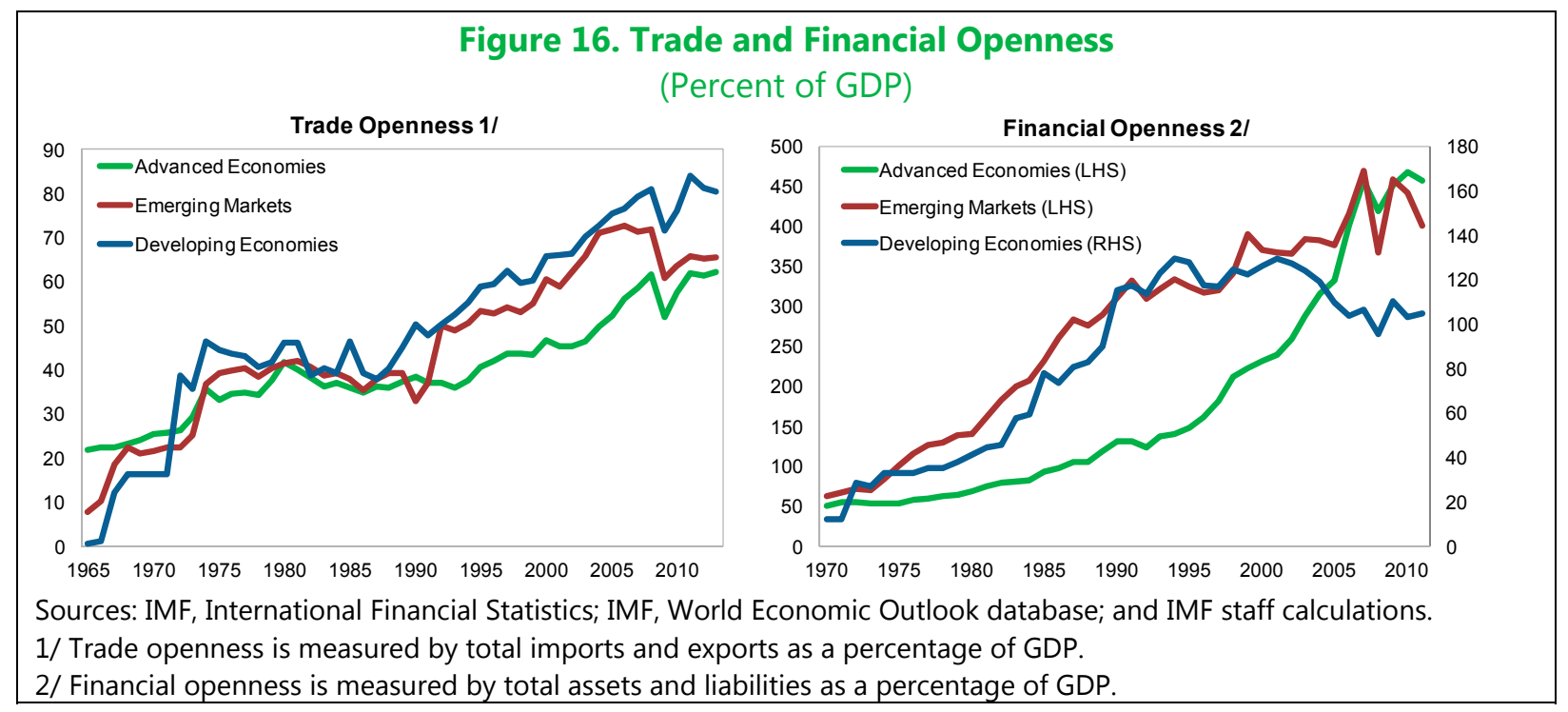

31. Financial globalization. Financial globalization can facilitate efficient international allocation of capital and promote international risk sharing. At the same time, increased financial flows, particularly foreign direct investment (FDI) and portfolio flows have been shown to increase income inequality in both advanced and emerging market economies (Freeman 2010). One potential explanation is the concentration of foreign assets and liabilities in relatively higher skill- and technology-intensive sectors, which pushes up the demand for and wages of higher skilled workers. In addition, FDI could induce skill-specific technological change, be associated with skill-specific wage bargaining, and result in more training for skilled than unskilled workers (Willem te Velde 2003). Moreover, low-skill, outward FDI from advanced economies may in effect be relatively highskilled, inward FDI in developing economies (Figini and Görg 2011), thus exacerbating the demand for high-skilled workers in recipient countries. Financial deregulation and globalization have also been cited as factors underlying the increase in financial wealth, relative skill intensity, and wages in the finance industry, one of the fastest growing sectors in advanced economies (Phillipon and Reshef 2012; Furceri and Loungani 2013).

32. Financial deepening. Financial deepening can provide households and firms with greater access to resources to meet their financial needs, such as saving for retirement, investing in education, capitalizing on business opportunities, and confronting shocks. Financial deepening accompanied by more inclusive financial systems can thus lower income inequality, while improving the allocation of resources (Dabla-Norris and others 2015). Theory, however, suggests that financial development could benefit the rich in the early stages of development, but the benefits become more broadly shared as economies develop (Greenwood and Jovanovic 1990). Indeed, some studies have found that financial development, measured as the relative share of the banking and stock market sectors in the economy, boosts top incomes the most in the early stages of development (Roine, Vlachos, and Waldenström 2009). Moreover, inequality can increase as those with higher incomes and assets have a disproportionately larger share of access to finance, serving to further increase the skill premium, and potentially the return to capital (Claessens and Perotti 2007). 


\section{Changes in labor market institutions.}

More flexible labor market institutions can foster economic dynamism by reallocating resources to more productive firms and enabling firm restructuring. However, greater flexibility can pose challenges for workers, especially those with low skills, and hence play an important role in explaining inequality developments (Alvadero and others 2013). A decline in trade union membership (union rate) could reduce the relative bargaining power of labor, exacerbating wage inequality (Frederiksen and Poulsen 2010; Wilkinson and Pickett 2010; Figure 17). ${ }^{9}$

Forthcoming IMF work finds that a reduction in the minimum wage relative to the median wage
Figure 17. Union Rate by Country Group (Percent)

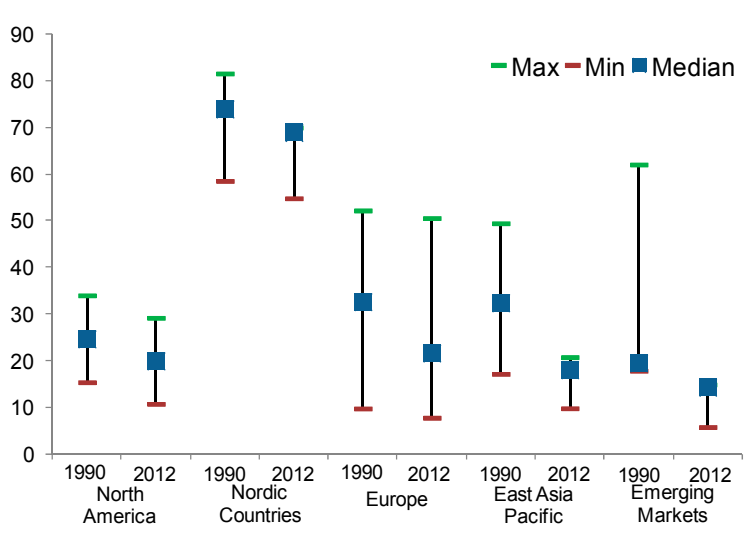

Sources: Organisation of Economic Co-operation and Development; and IMF staff calculations. is associated with higher inequality in advanced economies, while a decline in unionization rate is strongly associated with the rise of top income shares, though the impact can be partly mitigated by more collective bargaining coverage. Moreover, some studies have pointed to the role of wage dispersion and a higher share of part-time and temporary employment in driving inequality in labor earnings in some advanced economies (OECD 2012). For many labor market policies, such as reforms to employment protection legislation, the impact on inequality is less clear cut as they affect both the dispersion of earnings and the level of employment in sometimes conflicting ways. ${ }^{10}$ In many EMDCs, the combination of rigid hiring and firing and employment protection regulations and weak income protection systems often encourages informality, fueling wage inequality. However, evidence from a large sample of countries suggests that de facto labor market regulations (such as minimum wages, unionization, and social security contributions), on average, tend to improve the income distribution (Calderón and Chong 2009; OECD 2011).

34. Redistributive policies. Governments in advanced economies have historically mitigated inequality through public policy-primarily progressive taxes and social transfers such as public retirement benefits (CBO 2011). However, many advanced countries have now seen an increase in net income inequality, indicating gaps in existing tax-and-transfer systems to counteract rising market inequality. The progressivity of tax systems has declined in some advanced economies over the past few decades, with the result being that high-income households and corporations now face

\footnotetext{
${ }^{9}$ There is a difference between coverage rate of collective bargaining agreement and union density because in many advanced economies multi-employer bargaining and public policies extending the negotiated contract to nonorganized firms guarantee coverage rates in excess of density rates.

${ }^{10}$ Stronger labor market institutions could increase unemployment rates, reduce the wage differential between highskill and low-skill workers, and affect the labor share of income. The overall impact on income inequality, however, can be ambiguous: they increase unemployment, which tends to raise inequality, they can reduce wage dispersion, which tends to lower it, and they increase the wage share, which can have an ambiguous effect on inequality.
} 
lower effective tax rates (Hungerford 2013). ${ }^{11}$ Indeed, Figure 18 indicates that rising pre-tax income concentration at the top of the distribution in many advanced economies has also coincided with declining top marginal tax rates (from 59 percent in 1980 to 30 percent in 2009). Conditional cash transfers have become an important policy tool for directing resources towards the lower end of the distribution in EMDCs (IMF 2014a), but their redistributive impact varies widely across countries, reflecting both differences in the size and progressivity of these transfers.

35. Education. Education can play an important role in reducing income inequality, as it determines occupational choice, access to jobs, and the level of pay, and plays a pivotal role as a signal of ability and productivity in the job market. From a theoretical perspective, the human capital model of income distribution (Mincer, 1958; Becker and Chiswick, 1966) suggests that while there is an unambiguously positive association between educational and income inequality, the effect of increased educational attainment on income inequality could be either positive or negative depending on the evolution of rates of return to education (that is, the skill premium). Moreover, there can be opposing forces at play stemming from "composition" (that is, increasing the share of high-wage earners) and "wage compression" (that is, decline in the returns to higher education relative to lower levels) effects. Overall, the evidence suggests that the inequality impact of education depends on various factors, such as the size of education investments by individuals and governments and the rate of return on these investments. It is in this spirit that Rajan (2015) notes that "prosperity seems increasingly unreachable for many, because a good education, which seems to be today's passport to riches, is unaffordable for many in the middle class."

\section{B. Empirical Analysis}

\section{This section investigates the drivers of income inequality. ${ }^{12}$ The discussion above} suggests that a variety of inter-related factors can impact inequality and have potentially differential effects across countries and income groups. In this section, using a simple panel econometric

\footnotetext{
${ }^{11}$ Tax regimes can influence the mix of compensation, tilting it towards lower taxed forms of compensation, and thereby boost disposable income, particularly at the top. For example, capital gains are often taxed at a lower rate than other income and, in a few countries, they are not taxed at all. Stock options also benefit from preferential tax treatment in many advanced economies.

${ }^{12}$ We are unable to also investigate the drivers of wealth inequality due to data unavailability for a broad sample of advanced economies and EMDCs.
} 
approach with year and country fixed effects, we investigate the drivers of within country changes in income inequality for a sample of almost 100 advanced economies and EMDCs over the period 1980-2012 (see Box 1 for empirical specification). In contrast to other studies, we focus on a large group of countries to assess whether the determinants of inequality vary across advanced, emerging markets and developing economies, and across different measures of inequality. In addition to the Gini coefficients of both market and net inequality, we build on our earlier result that the income distribution itself matters for growth by examining the determinants of the disposable income shares (after tax) of the poor (bottom 10 percent), the middle-class (fifth decile), and the rich (top 10 percent). This allows us to focus on the factors driving income concentration in recent years, especially changes in the income shares of the poor and the middle class.

37. Drivers of gross and net inequality. Table 2 (Columns 1 and 2) presents the results of the regression analysis for gross and net inequality. Our results on the role of globalization and technological progress in driving inequality are broadly in line with the findings in the literature. In particular, trade openness is associated with lower inequality (albeit not in a statistically significant way), while greater financial openness and technological progress are associated with rising income inequality, likely reflecting the fact these disproportionately benefit high-tech and labor-skilled sectors. Indeed, we find that financial globalization and technological progress are associated with an increase in the top 10 percent disposable income share across all countries (Column 3).

38. Differential impacts of financial deepening across country groups. The impact of financial deepening, as proxied by the ratio of private credit to GDP, on both market and net inequality varies across advanced economies and EMDCs, in line with Roine, Vlachos, and

Waldenström 2009. In particular, our results suggest that financial deepening is associated with higher income inequality in EMDCs. This likely reflects the fact that while financial deepening has accelerated over the past two decades, the record on financial inclusion may not have kept apace in these countries. Indeed, Figure 19 indicates that financial deepening was associated with higher market and net income inequality in countries with low levels of financial inclusion (typically EMDCs), possibly reflecting that large amounts of credit are often concentrated among the largest firms and wealthier households. By contrast, financial deepening is associated with less of an increase in market inequality (and lower net inequality) in advanced economies, reflecting easier access to credit for households and firms.
Figure 19. Impact of Change in Financial Deepening on Inequality (Average in percentage points, 1990s-2011)

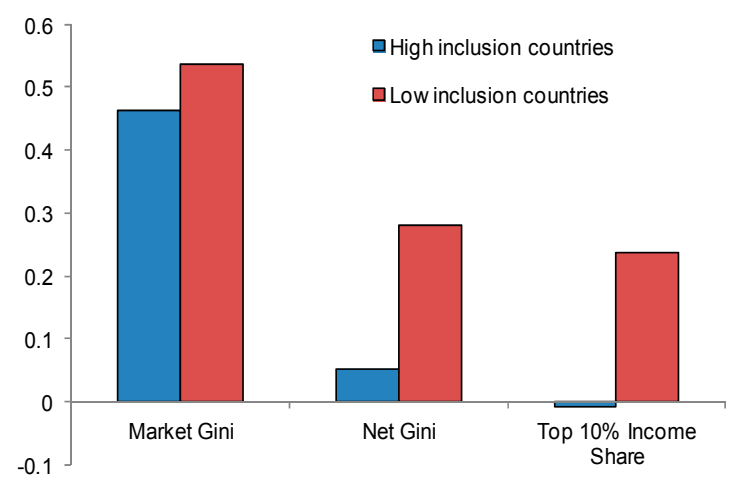

Source: World Bank, Global Financial Inclusion Database; World Bank, World Development Indicators; and IMF staff calculations.

Note: High (low) inclusion refers to countries above (below) the median value of the sample in terms of the proportion of the population with an account at a formal financial institution. 
Box 1. Assessing the Drivers of Income Inequality Around the World

Our empirical approach is based on a simple model of within-country variation in inequality, controlling for differences in levels across countries using five-year panels over the period 1980-2012. Specifically, the analysis builds on Jaumotte, Lall, and Papageorgiou (2013) and is based on the following specification:

$$
\begin{aligned}
\text { inequality }_{i t}= & \beta_{0} \text { trade }_{i t}+\beta_{1} \text { financial }_{i t}+\beta_{2} \text { technology }_{i t}+\beta_{3} \text { credit }_{i t}+\beta_{4} \mu_{A E} * \text { credit }_{i t} \\
& +\beta_{5} \text { skill premium }_{i t}+\beta_{6} \mu_{A E} * \text { skill premium } \\
i t & +\beta_{7} \text { education gini }_{i t} \\
& +\beta_{8} \text { labor flexibility }_{i t}+\beta_{9} \text { female mortality }_{i t}+\beta_{10} \text { governmenbt spending }_{i t}+\theta_{t}+\mu_{i} \\
& +\varepsilon_{i t}
\end{aligned}
$$

in which inequality $_{i t}$ refers to the relevant inequality measure used for country $i$ at time $t$, trade proxies for trade globalization, measured as the sum of exports and imports as a share of a country's GDP, financial captures financial globalization, measured as the sum of foreign assets and liabilities relative to GDP, and technology measures the share of information and communication technology (ICT) capital in the total capital stock. Credit captures domestic financial market development, and is proxied by the ratio of private credit to GDP. Since the effect of financial development could vary across advanced economies and EMDCs, we also include an interaction term between the credit variable and a dummy variable which takes the value of 1 for advanced economies, and zero otherwise. Given data limitations, and in line with Mincer's (1958) wage specification, we use the average years of education in the population aged 15 and older as a proxy for the skill premium. As noted in the literature, the effect of skill-biased technological change could vary across advanced economies and EMDCs. To capture this, we also include an interaction term between the skill premium variable and a dummy variable that takes the value of 1 for advanced economies, and zero otherwise. We also include a measure of labor market flexibility from the World Economic Forum that measures the extent by which regulations govern firing and hiring, collective bargaining, and minimum wages.

Additional control variables attempt to capture aspects of inequality of opportunities, including the beginning of period education Gini (a proxy for access to education); the quality and availability of health system is measured by the beginning of period female mortality (aged 15-60) rate. Given data limitations, as a proxy for redistributive policies, we include the beginning of period Fraser Institute index that measures total government spending as a share of GDP (see also Perotti [1992]).'The terms $\theta_{t}$ and $\mu_{i}$ represent a full set of time and country dummies, respectively, and $\varepsilon_{\text {it }}$ captures all the omitted factors. Country fixed effects allow us to focus on within-country changes instead of cross-country level differences. In addition, time dummies are included to capture the impact of common global shocks such as business cycles or growth spurts. All specifications include lagged GDP growth and share of employment in agriculture and industry as additional controls. Lagged GDP growth is included in the specifications as there could be a two way causality between output growth and inequality.

While causality is difficult to establish with full confidence, the results survive a variety of robustness checks for omitted variables, endogeneity problems, and estimation methods and are broadly in line with findings from the literature that focus on smaller country samples. For example, we checked the robustness of our results by including dummies for financial crises, GDP per capita, and alternative measures of the skill premium, trade, and financial openness. For some Organisation for Economic Cooperation and Development (OECD) countries with available tax and benefits data, we also considered alternative measures for redistributive policies as well as top marginal personal income-tax rates. The results, not reported here but available upon request, suggest that lower marginal tax rates are associated with higher market and net inequality and a higher income share of the top 10 percent. 


\begin{tabular}{|c|c|c|c|c|c|}
\hline \multicolumn{6}{|c|}{ Table 2. Regression Results of Inequality Drivers } \\
\hline Variables & $\begin{array}{c}\text { Market Gini } \\
\text { (1) }\end{array}$ & $\begin{array}{l}\text { Net Gini } \\
\text { (2) }\end{array}$ & $\begin{array}{c}\text { Top } 10 \% \\
\text { (3) }\end{array}$ & $\begin{array}{c}\text { 5th Income Decile } \\
\text { (4) }\end{array}$ & $\begin{array}{c}\text { Bottom } 10 \% \\
\text { (5) }\end{array}$ \\
\hline Trade openness & $\begin{array}{l}-0.025 \\
(0.017)\end{array}$ & $\begin{array}{l}-0.008 \\
(0.014)\end{array}$ & $\begin{array}{l}-0.011 \\
(0.014)\end{array}$ & $\begin{array}{c}0.002 \\
(0.003)\end{array}$ & $\begin{array}{c}0.005 \\
(0.005)\end{array}$ \\
\hline Financial openness & $\begin{array}{c}0.098 * * * \\
(0.016)\end{array}$ & $\begin{array}{l}0.047 * * \\
(0.019)\end{array}$ & $\begin{array}{l}0.026^{* *} \\
(0.011)\end{array}$ & $\begin{array}{l}-0.002 \\
(0.002)\end{array}$ & $\begin{array}{l}-0.008^{*} \\
(0.004)\end{array}$ \\
\hline Technology & $\begin{array}{l}56.85^{*} \\
(31.01)\end{array}$ & $\begin{array}{c}15.03 \\
(30.01)\end{array}$ & $\begin{array}{l}31.11^{*} \\
(15.81)\end{array}$ & $\begin{array}{l}-3.775 \\
(3.572)\end{array}$ & $\begin{array}{c}-11.51^{* * * *} \\
(3.587)\end{array}$ \\
\hline Financial deepening & $\begin{array}{c}0.050 * * \\
(0.021)\end{array}$ & $\begin{array}{c}0.026^{* *} \\
(0.011)\end{array}$ & $\begin{array}{c}0.022 * * * \\
(0.007)\end{array}$ & $\begin{array}{l}-0.004 \\
(0.001)\end{array}$ & $\begin{array}{l}-0.002 \\
(0.002)\end{array}$ \\
\hline AEs * Financial deepening & $\begin{array}{c}-0.049 * * \\
(0.021)\end{array}$ & $\begin{array}{c}-0.033^{* *} \\
(0.014)\end{array}$ & $\begin{array}{c}-0.03 * * * \\
(0.008)\end{array}$ & $\begin{array}{c}0.007 * * * \\
(0.002)\end{array}$ & $\begin{array}{l}0.004^{*} \\
(0.002)\end{array}$ \\
\hline Skill Premium & $\begin{array}{l}-0.413 \\
(0.726)\end{array}$ & $\begin{array}{l}-1.351 \\
(0.859)\end{array}$ & $\begin{array}{l}-0.475 \\
(0.670)\end{array}$ & $\begin{array}{c}0.063 \\
(0.110)\end{array}$ & $\begin{array}{l}-0.083 \\
(0.139)\end{array}$ \\
\hline AEs * Skill Premium & $\begin{array}{l}1.165^{* *} \\
(0.521)\end{array}$ & $\begin{array}{c}0.555 \\
(0.556)\end{array}$ & $\begin{array}{l}1.184 * * * \\
(0.346)\end{array}$ & $\begin{array}{c}-0.131^{* *} \\
(0.064)\end{array}$ & $\begin{array}{c}0.024 \\
(0.057)\end{array}$ \\
\hline Education Gini & $\begin{array}{c}6.085 \\
(10.94)\end{array}$ & $\begin{array}{l}-3.245 \\
(11.39)\end{array}$ & $\begin{array}{c}12.52 \\
(8.104)\end{array}$ & $\begin{array}{l}-1.906 \\
(1.364)\end{array}$ & $\begin{array}{l}-3.370^{*} \\
(1.721)\end{array}$ \\
\hline Labor Market Institutions & $\begin{array}{c}0.803 * * * \\
(0.291)\end{array}$ & $\begin{array}{c}0.497 \\
(0.320)\end{array}$ & $\begin{array}{l}0.338^{*} \\
(0.195)\end{array}$ & $\begin{array}{l}-0.045 \\
(0.036)\end{array}$ & $\begin{array}{c}-0.140 * * \\
(0.063)\end{array}$ \\
\hline Female Mortality & $\begin{array}{c}0.021 * * \\
(0.009)\end{array}$ & $\begin{array}{c}0.015^{*} \\
(0.009)\end{array}$ & $\begin{array}{c}0.026 \\
(0.032)\end{array}$ & $\begin{array}{c}-0.005^{* * *} \\
(0.002)\end{array}$ & $\begin{array}{c}0.001 \\
(0.002)\end{array}$ \\
\hline Government Spending & $\begin{array}{c}-0.26 \\
(0.162)\end{array}$ & $\begin{array}{c}-0.426^{* * *} \\
(0.145)\end{array}$ & $\begin{array}{c}-0.349 * * * \\
(0.103)\end{array}$ & $\begin{array}{c}0.046^{* * *} \\
(0.017)\end{array}$ & $\begin{array}{c}0.0332 \\
(0.023)\end{array}$ \\
\hline Country Fixed Effects & Yes & Yes & Yes & Yes & Yes \\
\hline Time Dummies & Yes & Yes & Yes & Yes & Yes \\
\hline \#. of Observations & 361 & 361 & 220 & 220 & 220 \\
\hline \#. of countries & 97 & 97 & 67 & 67 & 67 \\
\hline Adjusted R-squared & 0.386 & 0.246 & 0.491 & 0.412 & 0.225 \\
\hline $\begin{array}{l}\text { Sources: Fraser Institute; I } \\
\text { Database; World Bank; W } \\
\text { Note: Standard errors in p } \\
\text { regressions with robust st } \\
\text { growth and share of empl } \\
\text { incomes or consumption }\end{array}$ & $\begin{array}{l}\text { rld Economic } \\
\text { nomic Forum } \\
\text { ses, }{ }^{*} p<0.1 \\
\text { errors cluster } \\
\text { in agricultur } \\
\text { n household }\end{array}$ & $\begin{array}{l}\text { ok; Solt Da } \\
\text { IMF staff } \\
0.05 ; \text { and } \\
\text { the count } \\
\text { industry. } \\
\text { AEs = adv }\end{array}$ & $\begin{array}{l}\text { e; UNU-WI } \\
\text { ations. } \\
\text { <. } 01 \text {. Esti } \\
\text { eld Adition } \\
\text { e shares re } \\
\text { economie }\end{array}$ & $\begin{array}{l}\text { R World Income Ir } \\
\text { controls include la } \\
\text { esent disposable }\end{array}$ & $\begin{array}{l}\text { quality } \\
\text { cts panel } \\
\text { ged GDP } \\
\text { ter tax) }\end{array}$ \\
\hline
\end{tabular}

39. Higher skill premium is associated with widening inequality in advanced economies. In advanced economies, increases in the skill premium exacerbate market income inequality, reflecting the fact that education gains accrue disproportionately at the higher end of the income distribution. ${ }^{13}$ The statistically insignificant effect of the skill premium in driving net income inequality, however, could reflect the fact that the net Gini is underestimating increases in inequality at the top of the distribution (Kakwani 1980). Indeed, an increase in the skill premium is associated

${ }^{13}$ Our specification uses the average years of education in the population as a proxy for skills; see also Card and DiNardo (2000), essentially implying that the skill premium is determined solely by the supply of skills. Similar results were obtained using alternative measures, such the ratio of earnings from employment after completing tertiary education compared to the earnings after completing upper- and post-secondary education for a smaller sample of OECD countries (available upon request). 
with a significantly higher disposable income share of the top 10 percent. This effect is found to be statistically insignificant in EMDCs, and is in line with studies that find an absence of a correlation between income differentials and the quantity of skills in these countries, likely reflecting large differences in factor endowments and capacity to absorb new technologies across EMDCs (Behar 2013).

\section{Easing of labor market regulations is associated with higher market inequality and} income share of the top $\mathbf{1 0}$ percent. In particular, a decline in organized labor institutions and the resultant easing of labor markets measured by an increase in labor market flexibilities index by $81 / 2$ percent-from the median to $60^{\text {th }}$ percentile-is associated with rising market inequality by 1.1 percent. The relationship between the top $10^{\text {th }}$ percentile income share and easing of labor market regulations is also positive and statistically significant (Column 3) for our sample of countries, likely reflecting the fact that labor market flexibility benefits the rich and reduces the bargaining power of lower-income workers. This result is consistent with forthcoming IMF work which finds that weakening of unions is associated with a higher top 10 percent income share for a smaller sample of advanced economies. ${ }^{14}$ Indeed, empirical estimations using more detailed data for OECD countries (not reported here, but available upon request) suggest that, in line with other forthcoming IMF work, more lax hiring and firing regulations, lower minimum wages relative to the median wage, and less prevalent collective bargaining and trade unions are associated with higher market inequality. The impact of labor market institutions on inequality, however, is somewhat blunted by government actions as shown by the statistically insignificant coefficient in the net Gini regression (Table 2, Column 2).

41. Government actions can contribute to greater equality. In particular, we find that an increase in our proxy for government redistributive spending relative to total spending by 7.1 percent (that is, a shift from the median value to the $60^{\text {th }}$ percentile) is associated with a 0.6 percent decrease in income inequality. While total government spending can be a poor proxy for the progressivity of tax-transfer systems, this result continues to hold for other measures of redistribution for a smaller sample of OECD countries (not reported here, but available upon request), suggesting that the composition of government spending is important for reducing inequality. ${ }^{15}$ Moreover, healthier societies, as proxied by a lower female mortality rate, tend to have lower income inequality. While causality is difficult to establish, the latter finding suggests that greater and more equal access to quality health services allows people to be more productive, thus lowering income disparities.

42. Overall contributors to changes in inequality. Based on the estimated models, the contributions of the various factors to the change in the market Gini coefficient can be calculated. ${ }^{16}$

\footnotetext{
${ }^{14}$ This finding is also in line with recent research that finds that wage inequality falls during periods when union density is increasing and rises when union membership is in decline (World Bank 2013).

15 Joumard, Pisu, and Bloch (2012) look at the role of taxes and transfers while OECD (2012b) looks at how education policies, progressive taxes and transfers can tackle inequality.

${ }^{16}$ These estimates are calculated as the average annual change in the respective variable multiplied by the corresponding coefficient estimate in Table 2, Column 1.
} 
We find that less-regulated labor markets, financial deepening, and technological progress largely explain the rise in market income inequality in our full sample over the last 30 years (Figure 20). Globalization (that is, financial openness) has played a smaller but reinforcing role, while improvements in health outcomes mitigated around $1 / 2$ percent of the almost 3 percentage points average increase in the Gini coefficient. The relative importance of the skill premium, globalization, technological progress, and financial deepening in driving inequality, however, varies across advanced economies and EMDCs.

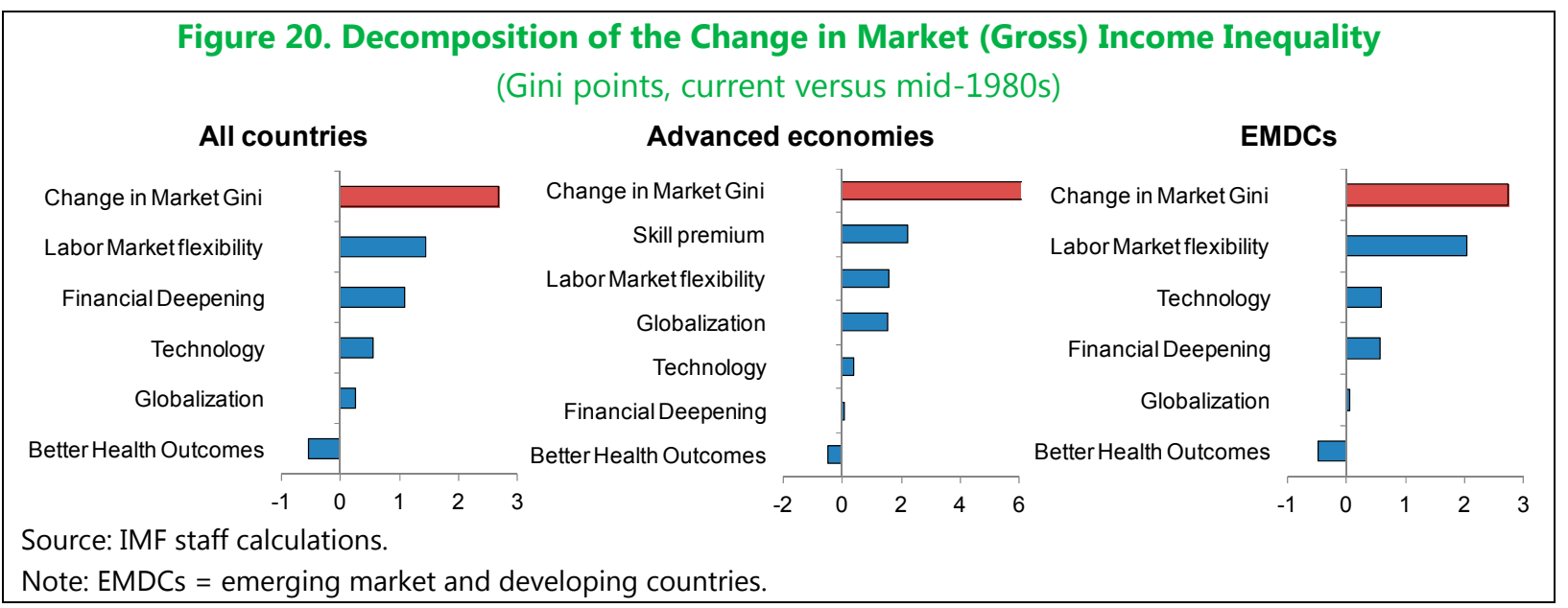

\section{What has been driving income shares of the poor and the middle class? Given the} importance of the poor (bottom 10 percent) and the middle class for boosting growth, we investigate what explains changes in the income shares for these income groups across different countries. On average, the income shares of the poor and the middle class have risen much more slowly than that of the top 10 percent, which explains the rising income inequality observed in many countries. Looking more closely into the determinants (Table 2, Columns 4 and 5, and Figure 21), we find:

- Better access to education (as captured by declining educational inequality), improved health outcomes, and redistributive social polices help raise the income share of the poor and the middle class irrespective of the level of economic development of a country. ${ }^{17}$ By contrast, easing of labor market regulations and technological progress dampen the income share of the poor and the middle class, consistent with other studies. This result is not surprising, since the poor are often disproportionally employed in lower-paying and less secure jobs (often in the informal sector) and tend to benefit more from labor market regulations such as minimum wages and firing restrictions. This points to the policy role of making education more accessible (Bruckner, Dabla-Norris, and Gradstein 2015), while ensuring that changes in labor market institutions do not excessively penalize lower-income individuals. Moreover, to the extent that

\footnotetext{
${ }^{17}$ In a recent speech, Rajan (2015) refers to economic inclusion-easing access to quality education, nutrition, health care, finance, and markets to all our citizens, as a "necessity for sustainable growth," in addition to "obviously, a moral imperative."
} 
redistributive policies can play a role in reducing inequality, they can be supported by making the tax systems more efficient and progressive and improving targeted spending.

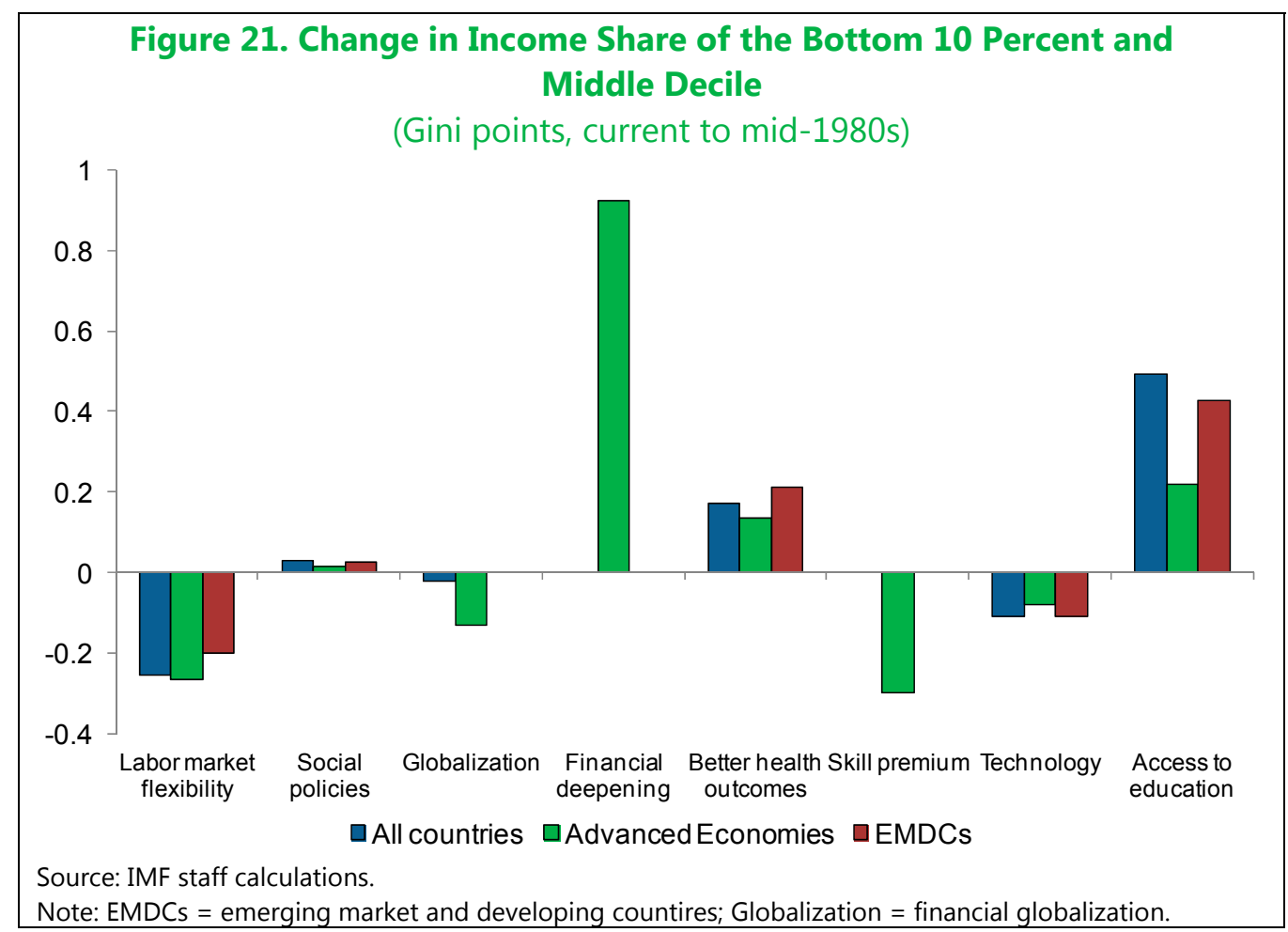

- There are important differences in inequality drivers between advanced economies and EMDCs, suggesting the need to tailor policies to country-specific conditions. In particular, we find that financial deepening has played a role in raising the income shares of the poor and the middle class in advanced economies, but not in EMDCs, likely reflecting differences in credit allocation and the extent of financial inclusion. In contrast, reducing gaps in access to education has been one of the most important drivers of higher income shares for the bottom 10 percent and the middle class in EMDCs. A complementary way to look at the income share of the poor is to examine the drivers of the interplay between inequality and the poverty rate-defined as the population living below $\$ 2$ a day (Box 2 ). Our findings suggest that greater equality in access to education lifts the poverty elasticity of economic growth.

- Financial globalization and a higher skill premium have accounted for a more significant share of the widening income gap between the top 10 percent and the poor and the middle class in advanced economies than in developing countries. Policies to raise skills and reforms to increase human capital are thus important for improving living standards and reducing labor income inequality in advanced economies. In contrast to conventional wisdom, our results suggest that globalization has played a less significant role in driving down income shares of the bottom 10 percent and the middle class in EMDCs (see also Box 2), suggesting that the benefits of globalization discussed earlier potentially outweigh the costs in some of these countries. 


\section{Box 2. Drivers of Poverty}

Another way to look at the income shares of the poor is to examine the drivers of poverty rate-defined as the population living below $\$ 2$ a day (PPP-adjusted) —and look at the interplay between poverty and inequality. The literature points to various sources for poverty reduction, including higher economic growth (Dollar, Kleineberg, and Kraay 2013) and a rise in the income share of the poor (Ravallion 2004). A large strand of the literature also explores how inequality affects poverty reduction via its growth impact; see for example, Bourguignon (2003) and Fosu (2010).

Using a sample of almost 100 EMDCs for the period 1985-2010, we investigate what is behind the declining share of people living below the $\$ 2$ a day poverty line over the last 30 years. Following Bourguignon (2003), we first investigate the importance of inequality and growth on poverty reduction. Our results suggest that while the impact of the change in inequality, as measured by the Gini, does not appear to be significant per se, higher initial inequality lowers the growth elasticity of poverty reduction (Table 3, Column 1). Moreover, a higher initial level of education inequality dampens the growth elasticity of poverty, while a higher employment growth in manufacturing, as seen in emerging market economies in Asia for instance, is associated with a lower share of the population living below the poverty line (Column 2). We also find that greater trade openness can amplify the growth elasticity of poverty, albeit not in a statistically significant way, while financial openness amplifies it in a significant way (Column 3).

\begin{tabular}{|c|c|c|c|}
\hline \multirow[b]{2}{*}{ Variables } & \multicolumn{3}{|c|}{$\begin{array}{l}\text { Population Share Living Below \$2/day } \\
\text { (percentage change) }\end{array}$} \\
\hline & (1) & (2) & (3) \\
\hline GDP per capita growth & $\begin{array}{c}-0.278 * * * \\
0.094\end{array}$ & $\begin{array}{c}-0.323^{* * *} \\
0.086\end{array}$ & $\begin{array}{c}-0.256^{* * *} \\
0.086\end{array}$ \\
\hline Initial Gini * GDP Per Capita Growth & $\begin{array}{c}0.005^{* *} \\
0.002\end{array}$ & $\begin{array}{l}0.003 \\
0.002\end{array}$ & $\begin{array}{c}0.005^{* *} \\
0.002\end{array}$ \\
\hline Change in Gini & $\begin{array}{c}0.296 \\
(0.356)\end{array}$ & & \\
\hline Initial Education Gini * GDP Per Capita Growth & & $\begin{array}{c}0.609 * * \\
(0.230)\end{array}$ & \\
\hline Employment in the Industrial Sector Growth & & $\begin{array}{c}-4.096^{* * *} \\
(0.926)\end{array}$ & \\
\hline Change in Trade Openness & & & $\begin{array}{c}1.009 \\
(1.153)\end{array}$ \\
\hline Change in Trade Openness * GDP Per Capita Growth & & & $\begin{array}{c}-0.151 \\
(0.107)\end{array}$ \\
\hline Change in Financial Openness & & & $\begin{array}{c}0.509 \\
(0.640)\end{array}$ \\
\hline Change in Financial Openness * GDP Per Capita Growth & & & $\begin{array}{c}-0.515^{* * *} \\
(0.122)\end{array}$ \\
\hline Constant & $\begin{array}{c}0.122 \\
(0.155) \\
\end{array}$ & $\begin{array}{c}0.100 \\
(0.153) \\
\end{array}$ & $\begin{array}{c}0.110 \\
(0.189) \\
\end{array}$ \\
\hline \#. of Observations & 282 & 180 & 272 \\
\hline R-squrared & 0.422 & 0.403 & 0.526 \\
\hline Adjusted R-squared & 0.405 & 0.371 & 0.506 \\
\hline $\begin{array}{l}\text { es: Solt Database; UNU-WIDER World Income Inequ } \\
\text { ok; and IMF staff calculations. } \\
\text { Heteroskedasticity-consistent standard errors in par } \\
\text { ared by Veronique Salins }\end{array}$ & theses, ${ }^{*} p$ & $\begin{array}{l}\text { Vorld Bank } \\
.1 ;{ }^{* *} p<0\end{array}$ & $\begin{array}{l}\text { World Economic } \\
5 ;{ }^{* * *} \mathrm{p}<0.01\end{array}$ \\
\hline
\end{tabular}


44. Caveats. We should of course be cautious about drawing definitive policy implications from cross-country regression analysis, as different policies are likely to have varying effects across countries and at different points in time. Measurement limitations in comparing inequality across time and countries also need to be considered. In addition, it is hard to go from the sorts of correlations presented in the note to firm statements about causality as there can be a two-way causality running from growth-to-income inequality. Indeed, in-depth country-specific analyses suggest that a number of inter-related factors drive growth, the income level, and income inequality. Despite these limitations, our analysis points to a policy role for tackling inequality.

\section{POLICY DISCUSSION AND FINAL REMARKS}

45. No one-size-fits-all. Policymakers around the world need to consider policies to tackle inequality. Raising the income share of the poor, and ensuring that there is no hollowing-out of the middle class is actually good for growth. Our empirical analysis also suggests that the drivers of inequality and their impact differ across countries for different income groups. As such, the nature of appropriate policies would necessarily vary across countries, and would also need to take into account country-specific policy and institutional settings, and capacity/implementation constraints. Recent work by the World Bank (2015) also highlights the importance of adopting a psychological and social perspective on policymaking that takes into account what policy is implemented and how.

46. Squaring equity and efficiency concerns. Lowering income inequality does not need to come at the cost of lower efficiency. Previous IMF work has shown that there does not need to be a stark efficiency-equity tradeoff (Ostry, Berg, and Tsangarides 2014). Redistribution through the tax and transfer system is found to be positively related to growth for most countries, and is negatively related to growth only for the most strongly redistributive countries. This suggests that the effect of redistribution on enhanced opportunities for lower-income households and on social and political stability could potentially outweigh any negative effects on growth through a damping of incentives.

47. Fiscal policy can be an important tool for reducing inequality. Fiscal policy plays a critical role in ensuring macrofinancial stability and can thus help avert/minimize crises that disproportionately hurt the disadvantaged population. At the same time, fiscal redistribution, carried out in a manner that is consistent with other macroeconomic objectives, can help raise the income share of the poor and middle class, and thus support growth. Fiscal policy already plays a significant role in addressing income inequality in many advanced economies, but the redistributive role of fiscal policy could be reinforced by greater reliance on wealth and property taxes, more progressive income taxation, removing opportunities for tax avoidance and evasion, better targeting of social benefits while also minimizing efficiency costs, in terms of incentives to work and save (IMF 2014a). In addition, reducing tax expenditures that benefit high-income groups most and removing tax relief-such as reduced taxation of capital gains, stock options, and carried interest-would increase equity and allow a growth-enhancing cut in marginal labor income tax rates in some countries. In EMDCs, better access to education and health services, well-targeted conditional cash transfers and more efficient safety nets can have a positive impact on disposable incomes of the poor (Bastagli, Coady and Gupta 2012). In many cases, this increasing public spending would need to be 
undertaken in tandem with rising revenue mobilization, reduced tax loopholes, and tax evasion, and lower less- well-targeted spending (such as oil subsidies).

48. Education policies are key. In a world in which technological change is increasing productivity and simultaneously mechanizing jobs, raising skill levels is critical for reducing the dispersion of earnings. Improving education quality, eliminating financial barriers to higher education, and providing support for apprenticeship programs are all key to boosting skill levels in both tradable and nontradable sectors. These policies can also help improve the income prospects of future generations as educated individuals are better able to cope with technological and other changes that directly influence productivity levels. In advanced economies, with an already high share of secondary or tertiary graduates among the working-age population, policies that improve the quality of upper secondary or tertiary education would be important. In developing countries with currently low levels of education attainment, policies that promote more equal access to basic education (for example, cash transfers aimed at encouraging better attendance at primary schools, or spending on public education that benefits the poor) could help reduce inequality by facilitating the accumulation of human capital, and making educational opportunities less dependent on socioeconomic circumstances.

49. Fostering financial inclusion safely. Financial deepening in EMDCs needs to be accompanied by greater inclusion to make a dent in inequality. Governments have a central role to play in alleviating impediments to financial inclusion by creating the associated legal and regulatory framework (for example, protecting creditor rights, regulating business conduct, and overseeing recourse mechanisms to protect consumers), supporting the information environment (for example, setting standards for disclosure and transparency and promoting credit information-sharing systems and collateral registries), and educating and protecting consumers. Country experiences also suggest that policies such as granting exemptions from onerous documentation requirements, requiring banks to offer basic accounts, and allowing correspondent banking are useful in fostering inclusion. The promotion of credit without sufficient regard for financial stability, however, can result in crises, as evidenced by the subprime mortgage crisis in the United States, with disproportionately adverse effects on the poor and the middle class. Moreover, it illustrates the broader point that deep social issues cannot be resolved purely with an infusion of credit. Policies thus need to strike a balance between fostering prudence stability, and inclusion, while encouraging innovation and creativity.

\section{Well-designed labor market policies and institutions can reduce inequality, and, at the} same time, not be a drag on efficiency. Policies that reduce labor market imperfections and institutional failures that affect job creation can help support poor and middle-income workers. For instance, appropriately set minimum wages, spending on well-designed active labor market policies aimed at supporting job search and skill matching can be important. Better use of in-work benefits for social benefit recipients also help reduce income disparities. Moreover, policies that reduce labor market dualism, such as gaps in employment protection between permanent and temporary workers - especially young workers and immigrants — can help to reduce inequality, while fostering greater market flexibility. More generally, labor market policies should attempt to avoid either excessive regulations or extreme disregard for labor conditions. Labor market rules that are very 
weak or programs that are nonexistent can leave problems of poor information, unequal power, and inadequate risk management untreated, penalizing the poor and the middle class (World Bank 2012). In contrast, excessively stringent regulations can compound market imperfections with institutional failures, and weigh on job creation and efficiency.

\section{In EMDCs, making labor markets more inclusive and creating incentives for lowering} informality is a key challenge. Workers in these countries often lack equal access to productive job opportunities and do not benefit evenly from economic growth. Many individuals with low skills, in particular, remain trapped in precarious jobs, often in the informal and unregulated economy. In such jobs, even full-time employment tends to be insufficient to lift households out of poverty. Thus, creating accessible, productive, and rewarding jobs is key to escaping poverty and reducing inequality. Informal workers need to have the necessary legal, financial, and educational means to access formal sector employment. Higher formal sector employment also requires better incentives for firms to become formal. Policies to reduce tax, financial, and regulatory constraints can expand formal sectoral employment by reducing the incentives for firms to operate informally, both by increasing the benefits of participating in the formal sector and by reducing the costs of doing so (Dabla-Norris and Inchauste 2008).

52. Complementarities between growth and income equality objectives. Reforms aimed at raising average living standards can also influence the distribution of income. Indeed, tackling inequality goes beyond the remit of labor, social welfare, financial inclusion, and tax policies. The key to minimizing the downside of both globalization and technological change in advanced economies is a policy agenda of a race to the top, instead of a race to the bottom - an agenda that includes policies to encourage innovation, reduce burdensome product market regulations that stifle competition and technology diffusion, move goods produced upwards in the value chain, and ensure that this rise benefits everyone. In developing countries, raising agricultural productivity, rapid accumulation of capital, and technology diffusion in labor-intensive sectors can substantially lift growth and ensure that the fruits of prosperity are more broadly shared (Dabla-Norris and others 2013). Sustaining growth in emerging market economies will require more intensive patterns of growth, greater flexibility to shift resources within and across sectors, and the capacity to apply more knowledge and skill-intensive production techniques. Policies to improve skills for all, to ensure that a nation's infrastructure meets its needs, and to encourage innovation and technology adoption are thus all essential to driving growth and ensuring a more inclusive prosperity. 


\section{ANNEX I. DEFINITIONS AND SOURCES OF VARIABLES}

This annex provides the definition and the sources of the main variables used in the econometric analysis (Table A1).

\begin{tabular}{|c|c|c|c|}
\hline \multicolumn{4}{|c|}{ Table A1. Data Description } \\
\hline Indicator Name & Description & Data Source & Period \\
\hline \multicolumn{4}{|c|}{ Inequality and Poverty variables } \\
\hline Market Gini & $\begin{array}{l}\text { Gini index of distribution of income before taxes } \\
\text { and transfers }\end{array}$ & $\begin{array}{l}\text { Standardized World Income Inequality } \\
\text { database }\end{array}$ & $1980-2011$ \\
\hline Net Gini & $\begin{array}{l}\text { Gini index of distribution of income after taxes } \\
\text { and transfers }\end{array}$ & $\begin{array}{l}\text { Standardized World Income Inequality } \\
\text { database }\end{array}$ & $1980-2011$ \\
\hline Gini growth & $\begin{array}{l}\text { Growth of the Gini index of inequality in equalized } \\
\text { household market income }\end{array}$ & $\begin{array}{l}\text { Standardized World Income Inequality } \\
\text { database }\end{array}$ & $1980-2011$ \\
\hline $\begin{array}{l}\text { Shares of income } \\
\text { (deciles/quintiles) }\end{array}$ & $\begin{array}{l}\text { Share of net income accruing to each decile / } \\
\text { quintile of the income distribution }\end{array}$ & UNU-WIDER database & $1980-2012$ \\
\hline $\begin{array}{l}\text { Poverty Headcount ratio } \\
\text { growth }\end{array}$ & $\begin{array}{l}\text { Growth of the share of the population living with } \\
\$ 2 \text { per day or less }\end{array}$ & World Bank's Povcal database & $1980-2012$ \\
\hline \multicolumn{4}{|l|}{ Economic variables } \\
\hline GDP growth & Annual growth of real GDP & $\begin{array}{l}\text { World Bank's World Development } \\
\text { Indicators database }\end{array}$ & $1980-2013$ \\
\hline GDP per capita & $\begin{array}{l}\text { Real GDP per capita based on constant local } \\
\text { currency }\end{array}$ & World Economic Outlook & $1980-2012$ \\
\hline GDP per capita growth & $\begin{array}{l}\text { Annual percentage growth rate of GDP per capita } \\
\text { based on constant local currency }\end{array}$ & $\begin{array}{l}\text { World Bank's World Development } \\
\text { Indicators database }\end{array}$ & $1980-2011$ \\
\hline Trade Openness & $\begin{array}{l}\text { Exports plus imports (goods and services), in } \\
\text { percent of GDP }\end{array}$ & WEO Database & $1980-2013$ \\
\hline Financial Openness & External assets plus liabilities, in percent of GDP & $\begin{array}{l}\text { External Wealth of Nations Database, } \\
\text { WEO Database }\end{array}$ & $1980-2013$ \\
\hline Credit & $\begin{array}{l}\text { Domestic credit to the private sector in percent of } \\
\text { GDP }\end{array}$ & $\begin{array}{l}\text { World Bank's World Development } \\
\text { Indicators database }\end{array}$ & $1980-2012$ \\
\hline $\begin{array}{l}\text { Industrial employment } \\
\text { growth }\end{array}$ & $\begin{array}{l}\text { Growth of the employment in industry as a } \\
\text { percentage of total employment }\end{array}$ & $\begin{array}{l}\text { World Bank's World Development } \\
\text { Indicators database }\end{array}$ & $1980-2012$ \\
\hline Government spending & $\begin{array}{l}\text { Simple average of the three relevant sub-indexes } \\
\text { (transfers and subsidies, public consumption and } \\
\text { public investment) of the size-of-the-government } \\
\text { index }\end{array}$ & Fraser Institute & $1980-2010$ \\
\hline Technology & $\begin{array}{l}\text { Share of information and communication } \\
\text { technology capital in the total capital stock }\end{array}$ & Jorgenson, Dale and Khuong Vu (2011) & $1980-2010$ \\
\hline Labor market institutions & $\begin{array}{l}\text { Simple average of firing and hiring and collective } \\
\text { bargaining indexes }\end{array}$ & World Economic Forum & $1980-2010$ \\
\hline Education gini & $\begin{array}{l}\text { Gini index of distribution of educational } \\
\text { attainment }\end{array}$ & World Bank's Education Statistics & $1980-2010$ \\
\hline Skill Premium & Average number of total years of schooling & $\begin{array}{l}\text { Barro-Lee education attainment } \\
\text { dataset }\end{array}$ & $1980-2013$ \\
\hline Female mortality & $\begin{array}{l}\text { Probability of dying between the ages of } 15 \text { and } \\
60 \text { for women }\end{array}$ & $\begin{array}{l}\text { World Bank's World Development } \\
\text { Indicators database }\end{array}$ & $1980-2010$ \\
\hline
\end{tabular}




\section{References}

Acemoglu, D. 1998. "Why Do New Technologies Complement Skills? Directed Technical Change and Wage Inequality." Quarterly Journal of Economics 113 (4): 1055-89.

_. 2011. "Thoughts on Inequality and the Financial Crisis." Presentation at the American Economic Association Annual Meeting, January 7.

Aghion, P., E. Caroli, and C. Garcia-Penalosa. 1999. "Inequality and Economic Growth: The Perspective of the New Growth Theories." Journal of Economic Literature 37 (4): 1615-60.

Alvaredo, F., A. B. Atkinson, T. Piketty, E. Saez. 2013. "The Top 1 Percent in International and Historical Perspective." NBER Working Paper 19075, National Bureau of Economic Research, Cambridge, Massachusetts.

Atkinson, A.B., T. Piketty, and E. Saez. 2011. "Top Incomes in the Long Run of History." Journal of Economic Literature 49 (1): 3-71.

Autor, D. H. 2014. "Skills, Education, and the Rise of Earnings Inequality Among the 'Other 99 Percent.'" Science 344: 843-51.

— L. F. Katz, and M. S. Kearney. 2006. "The Polarization of the U.S. Labor Market." American Economic Review 96 (2): 189-94.

, W. R. Kerr, and A. D. Kugler. 2007. "Does Employment Protection Reduce Productivity? Evidence from US States." The Economic Journal 117 (June): F189-F217.

Bardhan, P. K. 2005. Scarcity, Conflicts, and Cooperation: Essays in the Political and Institutional Economics of Development. Cambridge, Massachusetts: MIT Press.

Barro, R. J. 2000. "Inequality and Growth in a Panel of Countries." Journal of Economic Growth. 5 (1): 5-32.

Bastagli, F., D. Coady, and S. Gupta. 2012. "Income Inequality and Fiscal Policy," IMF Staff Discussion Note 12/08, International Monetary Fund, Washington.

Becker, G. S., and B. R. Chiswick. 1966. "Education and the Distribution of Earnings." American Economic Review 56 (1/2): 358-69.

Behar, A. 2013. "The Endogenous Skill Bias of Technical Change and Inequality in Developing Countries." IMF Working Paper 13/50. International Monetary Fund, Washington.

Berg, A., and J. D. Ostry. 2011. "Inequality and Unsustainable Growth: Two Sides of the Same Coin?" IMF Staff Discussion Note 11/08, International Monetary Fund, Washington.

Bernanke, B. S., 2011, "Global Imbalances: Links to Economic and Financial Stability," Speech at the Banque de France Financial Stability Review Launch Event, Paris, France, February 18. 
Bourguignon, F. 2003. "The Growth Elasticity of Poverty Reduction: Explaining Heterogeneity across Countries and Time Periods." Inequality and Growth: Theory and Policy Implications. Cambridge, Massacusetts: MIT Press.

, and S. Dessus. 2009. "Equity and Development: Political Economy Considerations." In No Growth without Equity? Inequality, Interests, and Competition in Mexico, edited by S. Levy and M. Walton. Washington: World Bank/Palgrave MacMillan.

Brightman, C. 2014. "The Profits Bubble." Research Affiliates, Newport Beach, California.

Bruckner, M., E. Dabla-Norris, and M. Gradstein. Forthcoming. "National Income and Its Distribution." Journal of Economic Growth.

Calderón, C., and A. Chong. 2009. "Labor Market Institutions and Income Inequality: An Empirical Exploration." Public Choice 138(1): 65-81.

Card, D., and J. E. DiNardo. 2002. "Skill Biased Technological Change and Rising Wage Inequality: Some Problems and Puzzles." NBER Working Paper 8769, National Bureau of Economic Research, Cambridge, Massachusetts.

Carvalho, L., and A. Rezai. 2014. "Personal Income Inequality and Aggregate Demand." Working Paper 2014-23, Department of Economics, University of São Paulo, São Paulo.

Castello-Climent, A. and R. Domenech. 2014. "Capital and Income Inequality: Some Facts and Some Puzzles (Update of WP 12/28 published in October 2012)," Working Papers 1228, Economic Research Department, BBVA Bank, Madrid.

Cingano, F. 2014."Trends in Income Inequality and its Impact on Economic Growth", OECD Social, Employment and Migration Working Papers, No. 163, OECD Publishing.

Congressional Budget Office (CBO). 2011. "Trends in the Distribution of Household Income Between 1979 and 2007." Available at http://www.cbo.gov/sites/default/files/10-25HouseholdIncome 0.pdf

Claessens, S., and E. Perotti. 2007. "Finance and Inequality: Channels and Evidence." Journal of Comparative Economics 35 (4): 748-73.

Corak, M. 2013. "Income Inequality, Equality of Opportunity, and Intergenerational Mobility." Journal of Economic Perspectives. 27 (3): 79-102.

Credit Suisse, 2013. Global Wealth Report. Zurich: Credit Suisse AG.

Dabla-Norris, E., Y. Ji, R.M. Townsend, and D. Filiz Unsal. 2015. "Distinguishing Constraints of Financial Inclusion and Their Impact on GDP and Inequality." NBER Working Paper 20821, Cambridge, Massachusetts: National Bureau of Economic Research. 
_ G. Ho, K. Kochhar, A. Kyobe, and R. Tchaidze. 2013. "Anchoring Growth: The Importance of Productivity-Enhancing Reforms in Emerging Market and Developing Economies." Staff

Discussion Note 13/08, International Monetary Fund, Washington.

, and G. Inchauste. 2008. "Informality and Regulations: What Drives the Growth of Firms?" IMF Staff Papers 55 (1): 50-82.

— Consequences," IMF Working Paper 04/214, International Monetary Fund, Washington.

Davies, J. B., S. Sandström, A. Shorrocks, and E.N. Wolff. 2008. "The World Distribution of Household Wealth," Discussion Paper 2008/03, UNI-WIDER, Helsinki.

Dollar, D., T. Kleineberg, and A. Kraay. 2013. Growth Is Still Good for the Poor." World Bank Policy Research Paper 6568, World Bank, Washington.

Duclos, J., J. Esteban, and D. Ray. 2004. "Polarization: Concepts, Measurement, Estimation." Econometrica 72 (6): 1737-72.

Federal Reserve. 2014. 2013 Survey of Consumer Finances. Available at: http://www.federalreserve.gov/econresdata/scf/scfindex.htm

Feenstra, R., and G. H. Hanson. 1996. "Globalization, Outsourcing, and Wage Inequality." American Economic Review 86 (2): 240-45.

1999. "The Impact of Outsourcing and High-Technology Capital on Wages: Estimates for the United States, 1979-1990." Quarterly Journal of Economics 114 (3): 907-40.

2003. "Global Production Sharing and Rising Inequality: A Survey of Trade and Wage." In Handbook of International Trade, edited by E.K. Choi and J. Harrigan. Malden, Massachusetts: Blackwell.

Figini, P., and H. Görg. 2011. "Does Foreign Direct Investment Affect Wage Inequality? An Empirical Investigation." The World Economy 34 (9): 1455-75.

Fosu, A. K., 2010, "Growth, Inequality and Poverty Reduction in Developing Countries: Recent Global Evidence." OECD Background Paper for the Global Development Outlook, Organisation for Economic Co-operation and Development, Paris.

Frederiksen, A., and O. Poulsen. 2010. "Increasing Income Inequality: Productivity, Bargaining and Skill-Upgrading." IZA Discussion Papers 4791, Institute for the Study of Labor, Bonn, Germany.

Freeman, R. 2010. "Does Inequality Increase Economic Output?" In Controversies about Inequality. Stanford, CA: Stanford University Press. 
Furceri, D., and P. Loungani. 2013. "Who Let the Gini Out?" Finance \& Development 50 (4): 25-27.

Galor, O., and O. Moav. 2004. "From Physical to Human Capital Accumulation: Inequality and the Process of Development." Review of Economic Studies 71 (4): 1001-26.

Greenwood, J., and B. Jovanovic. 1990. "Financial Development, Growth, and the Income Distribution." Journal of Political Economy 98: 1076-1107.

Goos, M., A. Manning, and A. Salomons. 2009. "Job Polarization in Europe." American Economic Review 99 (2): 58-63.

Hairong, W. 2014. "The Wealthy Get Wealthier: Increasing Wealth Disparity in China Calls for Government Action." Beijing Review 42 (October 17).

Hungerford, T. L. 2013. "Changes in Income Inequality among U.S. Tax Filers between 1991 and 2006: The Role of Wages, Capital Income, and Taxes." Economic Policy Institute, Washington.

International Monetary Fund (IMF). 2014a. "Fiscal Policy and Income Inequality." IMF Policy Paper, Washington.

—. 2014b. Middle East And Central Asia-Regional Economic Outlook. Washington, October.

- S. Lall, and C. Papageorgiou. 2013. "Rising Income Inequality: Technology, or Trade and Financial Globalization?" IMF Economic Review 61 (2): 271-309.

Joumard, I., M. Pisu, and D. Bloch. 2012. "Tackling Income Inequality: The Role of Taxes and Transfers." OECD Journal: Economic Studies. 2 (1): 37-70.

Kakwani, N.C. 1980. Income Inequality and Poverty: Methods of Estimation and Policy Application. New York: Oxford University Press.

Krugman, P. 2014. "Why We Talk about the One Percent." New York Times, January 17.

Kumhof, M., and R. Rancière. 2010. "Inequality, Leverage, and Crises." IMF Working Paper 10/268, International Monetary Fund, Washington.

—, C. Lebarz, R. Rancière, A.W. Richter, and N.A. Throckmorton. 2012. "Income Inequality and Current Account Imbalances." IMF Working Paper 12/08 International Monetary Fund, Washington.

Lakner, C., and B. Milanovic. 2013. "Global Income Distribution: From the Fall of the Berlin Wall to the Great Recession." WB Policy Research Working Paper 6719, World Bank, Washington. 
Lazear, E., and S. Rosen. 1981. "Rank-Order Tournaments as Optimum Labor Contracts." Journal of Political Economy 89 (5): 841-64.

Lichbach, M. I. 1989. "An Evaluation of 'Does Economic Inequality Breed Political Conflict?' Studies." World Politics 41 (4): 431-70.

Milanovic, B. 2013. "Global Income Inequality by the Numbers: in History and Now." Global Policy 4 (2): 198-208.

Mincer, J., 1958. "Investment in Human Capital and Personal Income Distribution." Journal of Political Economy 66 (2): 281-302.

Munch, J. R., and R. Skaksen. 2009. "Human Capital and Wages in Exporting Firms." Working Paper 09-2006, Copenhagen Business School, Copenhagen.

Murray, C., A. Lopez, and M. Alvarado. 2013. "The State of US Health, 1990-2010: Burden of Diseases, Injuries, and Risk Factors." The Journal of the American Medical Association 310 (6): 591-606.

Organisation for Economic Co-operation and Development (OECD). 2011. Divided We Stand: Why Inequality Keeps Rising. Paris: OECD Publishing. . 2012a. "Inequality in Labor Income-What Are Its Drivers And How Can It Be Reduced?" OECD Economics Department Policy Note 8, Paris.

. 2012b. "Reducing Income Inequality While Boosting Economic Growth: Can It Be Done?" In Economic Policy Reforms: Going for Growth. Paris: OECD Publishing.

2014. "Rising Inequality: Youth and Poor Fall Further Behind." Income Inequality Update, Paris.

Ostry, J. D., A. Berg, and C. Tsangarides. 2014. "Redistribution, Inequality, and Growth." IMF Staff Discussion Note 14/02, International Monetary Fund, Washington.

Perotti, R. 1992. "Income Distribution, Politics, and Growth," American Economic Review, American Economic Association, 82(2): 311-16.

Pew Research Center (PRC). 2014. "Emerging and Developing Economies Much More Optimistic than Rich Countries about the Future." Washington.

Phillipon, T., and A. Reshef. 2012. "Wages and Human Capital in the U.S. Finance Industry: 19092006." Quarterly Journal of Economics 127 (4): 1551-1609.

Piketty, T. 2014. Capital in the Twenty-first Century. Cambridge, Massachusetts: Harvard University Press.

, and E. Saez. 2003 and 2011. "Income Inequality in the United States, 1913-1998." Quarterly Journal of Economics 118 (1): 1-39. 
—, and G. Zucman. 2014. "Capital is Back: Wealth-Income Ratios in Rich Countries 1700-2010." Quarterly Journal of Economics 129 (3): 1255-1310.

Putnam, R. D. 2000. Bowling Alone: The Collapse and Revival of American Community. New York: Simon \& Schuster.

Rajan, R.G. 2015. "Democracy, Inclusion, and Prosperity." Speech at the D.D. Kosambi Ideas Festival Goa, India, February 20.

_ 2010. Fault Lines. Princeton, New Jersey: Princeton University Press.

Ravallion, M. 2004. "Pro-Poor Growth: A Primer." Policy Research Working Paper Series 3242, World Bank, Washington.

Rawls, J. 1971. A Theory of Justice. Cambridge, Massachusetts: Harvard University Press.

Roine, J., J. Vlachos, and D. Waldenström. 2009. "The Long-Run Determinants of Inequality: What Can We Learn from Top Income Data?" Journal of Public Economics 93 (7/8): 974-88.

Saez, E. 2014 "Income Concentration and Top Income Tax Rates." Presentation at the Tax Policy Center \& USC Conference: Growing Income Inequality: Is Tax Policy the Cause, the Cure or or Irrelevant? USC Gould School of Law, Los Angeles, February 7.

Stiglitz, J. 2012. The Price of Inequality: How Today's Divided Society Endangers Our Future. New York: W.W. Norton.

Tsounta, E., and A. Osueke. 2014. "What Is Behind Latin America's Declining Income Inequality?" IMF Working Paper 14/124, International Monetary Fund, Washington.

Wilkinson, R., and K. Pickett. 2010. The Spirit Level: Why Equality is Better for Everyone. London: Penguin.

Willem te Velde, D. 2003 "Foreign Direct Investment and Income Inequality in Latin America." Overseas Development Institute, London.

World Bank. 2012. World Development Report. World Bank: Washington.

- 2013. World Development Report: Jobs World Bank: Washington. 2015. World Development Report: Mind, Society, and Behavior. World Bank: Washington.

Zhang, X., and R. Kanbur. 2011. "What Difference do Polarisation Measures Make? An Application to China." Journal of Development Studies 37 (3): 85-98.

Zhong, W., V. Vakulabharanam, S. Ruparelia, Y. Ming, A. Deshpande, and L. Banerjee. 2010. "Wealth Inequality: China and India." Working Paper, The New School, New York. 